\title{
What Determines Government Spending Multipliers?
}

Giancarlo Corsetti, Andre Meier, and Gernot J. Müller 


\title{
IMF Working Paper
}

Monetary and Capital Markets Department

\section{What Determines Government Spending Multipliers?}

\section{Prepared by Giancarlo Corsetti, Andre Meier, and Gernot J. Müller ${ }^{1}$}

\author{
Authorized for distribution by Peter Dattels
}

June 2012

This Working Paper should not be reported as representing the views of the IMF. The views expressed in this Working Paper are those of the author(s) and do not necessarily represent those of the IMF or IMF policy. Working Papers describe research in progress by the author(s) and are published to elicit comments and to further debate.

\begin{abstract}
This paper studies how the effects of government spending vary with the economic environment. Using a panel of OECD countries, we identify fiscal shocks as residuals from an estimated spending rule and trace their macroeconomic impact under different conditions regarding the exchange rate regime, public indebtedness, and health of the financial system. The unconditional responses to a positive spending shock broadly confirm earlier findings. However, conditional responses differ systematically across exchange rate regimes, as real appreciation and external deficits occur mainly under currency pegs. We also find output and consumption multipliers to be unusually high during times of financial crisis.
\end{abstract}

\section{JEL Classification Numbers: E62, E63, F41}

Keywords: Multiplier, fiscal policy, financial crisis, government spending, public finances, exchange rate regime

Author's E-Mail Address: giancarlo.corsetti@gmail.com, ameier@imf.org, and gernot.mueller@uni-bonn.de

\footnotetext{
${ }^{1}$ This paper is part of the project "International Dimensions of Fiscal Policy Transmission," sponsored by the Fondation Banque de France ( $11^{\text {th }}$ Call for Projects) in cooperation with the Center for Economic Policy Research. An earlier version of the paper was circulated under the title "When, Where, and How Does Government Spending Matter?" The current version was prepared for the Economic Policy Panel in Copenhagen. We thank Philip Lane and three anonymous referees for very useful comments. We also thank Giovanni Callegari, Bianca de Paoli, Robert Hall, Hubert Kempf, Mika Kortelainen, Daniel Leigh, Jesper Linde, Marialuz Moreno Badia, Silvia Sgherri, Mike Woodford and seminar participants at the Banco de Espana, Bank of England, Banque de France, CEPR ESSIM 2010, European Central Bank, the 2010 conference on "Global Dimensions of the Financial Crisis" at the Federal Reserve Bank of New York, and the Federal Reserve Board. Dominik Menno provided excellent research assistance. Corsetti and Müller gratefully acknowledge generous support from the Fondation Banque de France.
} 


\section{Introduction}

The widespread use of fiscal stimulus measures to counter the global financial crisis and the more recent shift toward fiscal tightening in many advanced economies have revived the longstanding debate on the size of the fiscal multiplier. From a theoretical perspective, however, there is no such thing as the multiplier. Instead, fiscal multipliers are likely to depend on a number of factors which vary both across countries and time. Traditional Mundell-Fleming analysis posits that the effectiveness of fiscal stabilization hinges on financial development, capital mobility, trade openness, and the exchange rate regime. In addition, the response of private demand to a fiscal intervention may also depend on the state of public finances. For instance, fiscal expansions at high levels of debt could play out differently if they increase the likelihood of a sharp future retrenchment. Another potential determinant is the health of the financial system, notably the extent to which the private sector has access to credit, given that binding liquidity constraints generally reinforce the impact of fiscal stimulus. In a similar vein, recent quantitative analysis predicts exceptionally large government spending multipliers during deep recessions when monetary policy is constrained by the zero lower bound on policy rates. ${ }^{1}$

In this paper, we carry out an empirical exploration into the determinants of government spending multipliers, by studying how the fiscal transmission mechanism depends on the economic environment. In terms of conditioning factors, we focus on the exchange rate regime, the level of public debt and the deficit, and the occurrence of a financial crisis. We conduct our analysis on a sample of 17 OECD countries for the period 1975-2008. For the classification of exchange rate regimes and financial crisis episodes we draw on Ilzetzki, Reinhart, and Rogoff (2009), Reinhart and Rogoff (2008), and Reinhart (2010).

Prior empirical work on fiscal policy transmission has mostly relied on linear time series models estimated on U.S. data. Indeed, an extensive literature has clarified key issues in identification, providing alternative strategies for quantifying the effects of fiscal policy measures; see Blanchard and Perotti (2002), Mountford and Uhlig (2009), and Ramey (2011), among others. At the same time, there are relatively few empirical studies examining the dependence of fiscal policy effects on economic environments, notably Perotti (1999), Giavazzi, Jappelli, and Pagano (2000) and, more recently, Tagkalakis (2008), Ilzetzki, Mendoza, and Vegh (2011), and Auerbach and Gorodnichenko (2010, 2011). Even less empirical work has been devoted to the question of how fiscal transmission changes during times of financial crisis. ${ }^{2}$

\footnotetext{
${ }^{1}$ For insightful theoretical analyses of the latter three aspects, see Bertola and Drazen (1993), Galí, López-Salido, and Vallés (2007), and Christiano, Eichenbaum, and Rebelo (2011), respectively. Corsetti, Kuester, Meier, and Müller (2012) analyze how deep recessions interact with strained public finances in shaping fiscal policy transmission.

${ }^{2}$ See Baldacci, Gupta, and Mulas-Granados (2001) and International Monetary Fund (2009) for an investigation into how fiscal policy may mitigate deep recessions.
} 
Drawing on the work by Perotti (1999), we employ a flexible two-stage strategy that allows us to exploit variation in economic conditions across space and time to gauge their impact on fiscal policy transmission. In a first step, we estimate a fiscal policy rule that is meant to describe the statistical process of government spending and provide estimates of spending shocks. The rule we consider is very similar to the structure embedded in fiscal policy vector autoregressions (VARs), linking our approach to an identification strategy commonly found in the literature. In a second step, we use contemporaneous and lagged values of the estimated policy shocks to trace the dynamic effects of government spending on several macroeconomic variables of interest. We study the role of different economic environments in shaping fiscal transmission by interacting the shocks with dummies for the exchange rate regime, the state of public finances, and the occurrence of a financial crisis.

To set the stage for our analysis, we initially estimate our model abstracting from any of these interactions. In this case, our two-step procedure yields a series of results for the unconditional (or average) behavior and impact of fiscal policy that accord well with earlier findings from the literature. First, the estimated spending rules suggest that government spending exhibits no clear cyclical pattern, but responds negatively to weak public finances, thus contributing to debt stabilization. Second, in response to an unexpected increase in government spending, we find a positive, if relatively contained increase in output, almost no response of consumption, and some crowding-out of investment and net exports. Moreover, the spending shock prompts a short-lived real appreciation, followed by a weakening of the real exchange rate.

However, these unconditional results mask important differences in the transmission of fiscal shocks across economic environments. Once we turn to our fully specified model including three sets of conditioning variables, the following picture emerges. Under a flexible exchange rate, with low debt levels and no financial crisis, we find no appreciable effects of government spending shocks except on investment, which declines, and the real exchange rate, which weakens over time. Relative to this baseline scenario, a pegged currency implies a larger trade deficit, but no real exchange depreciation on impact. For most specifications, we also find spending-side stimulus to be more effective under a peg, in line with conventional wisdom. Specifically, the response of output is larger, and investment falls by less. ${ }^{3}$ If public debt or the deficit is high, the impact responses of output and investment are lower than in the baseline scenario. Yet the differences are very moderate, perhaps pointing to the limitation of our fiscal metrics in capturing the overall health of public finances. A more striking set of findings emerges for the case of fiscal policy transmission during times of financial crisis. Indeed, the responses of output and consumption to a public spending increase are strongly positive during such times, implying a fiscal multiplier of up to two. In addition, we find a considerably more pronounced decline of net exports and the real exchange rate.

\footnotetext{
${ }^{3}$ While differences in the response of external variables across currency regimes are quite robust, differences in the response of other macroeconomic aggregates are somewhat more sensitive to the specification of the model.
} 
As the number of observations in our sample is limited and fiscal shocks may be measured with error, confidence intervals are, in general, quite wide, and point estimates must be taken with a grain of salt. Yet our main conclusions, especially regarding the effects of government spending shocks during financial crises, appear to be robust with respect to a number of variations in our empirical setup. Most closely related to our work is independent research by Ilzetzki et al. (2011), who also analyze the transmission of fiscal policy across different economic environments. In contrast to our study, these authors use quarterly time-series data for both OECD and emerging market countries, estimating panel VARs for groups of countries distinguished by income level, the size of foreign debt, the exchange rate regime, openness, and the degree of capacity utilization. Their approach, however, isolates only one dimension at a time. In terms of results, there are significant similarities, especially regarding the output multiplier across exchange rate regimes, but also differences, notably with respect to the degree of monetary accommodation and exchange rate appreciation under a peg. Notwithstanding these differences, both studies clearly underscore the case for investigating fiscal policy transmission conditional on the economic, financial, and policy environment.

The remainder of this paper is organized as follows. Section 2 provides a brief theoretical discussion of why the fiscal transmission mechanism may differ across economic environments. Section 3 introduces our two-step estimation approach in detail. Sections 4 and 5 present the main results for the first and second step, respectively; and Section 6 concludes.

\section{Fiscal policy in different economic environments}

The very active use of fiscal policy since the start of the global financial crisis-first to counter the downturn with fiscal stimulus and, more recently, to rein in high deficits amid bond market pressures in the euro area-has revived longstanding policy debates and drawn attention to an important theoretical insight: there is unlikely to be such a thing as "the" fiscal multiplier. Instead, it seems reasonable to expect that multipliers depend on current circumstances as well as underlying economic structures and policy regimes (quite aside from any variation related to the specific fiscal measure at hand). Accordingly, the likely impact of fiscal policy cannot be assessed without proper consideration of the key factors characterizing the economic environment across countries and over time. In this paper, we emphasize, in particular, the role of exchange rate regimes, the state of public finances, and the health of the financial sector. Before assessing their relevance for fiscal transmission empirically, we briefly review in this section some key theoretical contributions that guide our empirical analysis.

\subsection{A theoretical benchmark}

The theoretical debate on the fiscal transmission mechanism has traditionally focused on the response of private consumption to an increase in government spending. Indeed, the consumption response 
not only has quantitatively important implications for the size of the government spending multiplier on output, but it also serves to discriminate between the opposing predictions of key macroeconomic models. Modern business cycle models, of both neoclassical and new Keynesian varieties, view private consumption as governed by intertemporal optimization. This generally implies that private consumption falls in response to an increase in government spending. ${ }^{4}$ As a result, output multipliers are considerably smaller than would be suggested by more traditional Keynesian analysis, which predicts a positive consumption response. For instance, in a seminal study based on the frictionless neoclassical model, Baxter and King (1993) consider various specifications for household preferences and the duration of fiscal stimulus, but find that impact multipliers on output hardly ever exceed unity. ${ }^{5}$ Subsequent research has further refined the theoretical analysis of fiscal transmission. However, much of this research has been confined to standard business cycle models, abstracting from the exchange rate regime, government debt, and financial frictions. We discuss a few notable exceptions below.

\subsection{Pegged exchange rates}

In open economies with a high degree of capital mobility, the choice of the exchange rate regime determines the scope for independent monetary policy. This consideration is central to fiscal policy analysis within the traditional Mundell-Fleming framework. In the typical textbook experiment, government spending is ineffective in stimulating domestic economic activity under flexible exchange rates: assuming an unchanged monetary stance, a fiscal expansion crowds out net exports one-forone as the exchange rate appreciates. Only under fixed exchange rates does fiscal policy become an effective stabilization tool, because any pressure toward exchange rate appreciation is immediately offset through monetary expansion. Although these specific predictions did not go unchallenged (see Dornbusch (1980) for an early critique), the traditional literature views the exchange rate regime as having a first-order effect on fiscal transmission.

The exchange rate regime continues to matter for fiscal multipliers in new Keynesian business cycle models, but the sharp predictions of traditional Keynesian theory do not necessarily go through. One key reason is the richer modeling of how fiscal and monetary policies interact. Indeed, fiscal stimulus can be either more or less effective under a flexible exchange rate in a new Keynesian model, depending on the precise assumptions about monetary policy and the medium-term debt consolidation

\footnotetext{
${ }^{4}$ Our discussion focuses on the transmission of government spending shocks assuming lump-sum financing. In line with much of the literature, we also assume that government spending does not affect the marginal utility of households nor the productive capacity of the private sector.

${ }^{5}$ Baxter and King (1993) also show that multipliers are much larger under the assumption that government spending enhances the productive capacity of the economy. By contrast, output multipliers are negative if government spending is financed by distortionary taxes, assuming balanced budgets. Linnemann and Schabert (2003) provide an early analysis within the new Keynesian baseline model. Cogan, Cwik, Taylor, and Wieland (2010), in turn, consider a richer business cycle model with a particular focus on quantifying the multiplier implied by actual fiscal policy measures implemented in the United States after 2009.
} 
framework; see Corsetti, Kuester, and Müller (2011a).

Aside from the role of exchange rate regimes in shaping fiscal policy transmission, the behavior of the exchange rate is also an important benchmark for assessing different macroeconomic theories, much like the behavior of private consumption already mentioned above. Most standard models predict that higher government spending appreciates the real exchange rate. ${ }^{6}$ Recently, however, several contributions have questioned this result, identifying conditions under which the opposite is true. Kollmann (2010), for instance, stresses that an increase in government spending may depreciate the real exchange rate if government spending shocks are very persistent and international financial markets incomplete. Ravn, Schmitt-Grohé, and Uribe (2012) arrive at the same conclusion by assuming that preferences of private households and the government are characterized by "deep habits." Under this assumption, imperfectly competitive producers find it optimal to lower markups and prices in the short run, so as to lock in higher public demand for the future. In equilibrium, the price of domestic consumption falls relative to foreign consumption, i.e., the real exchange rate depreciates.

In Corsetti, Meier, and Müller (2011b) we highlight that the impact of short-run fiscal stimulus, including on the exchange rate, crucially depends on the medium-term debt consolidation regime. Specifically, if government spending contributes to debt stabilization, higher spending today induces expectations of a systematic reduction in future spending plans. As a result, long-term real interest rates do not rise in response to the initial spending increase, and the real exchange rate depreciates. In this analysis, the exchange rate response is driven by the anticipated monetary policy response to future spending cuts. ${ }^{7}$

\subsection{Weak public finances}

In an influential study, Giavazzi and Pagano (1990) analyzed large-scale fiscal consolidations in Denmark and Ireland during the 1980s. These episodes were characterized by a coincidence of improving government balances and strong private consumption growth. While this positive

\footnotetext{
${ }^{6}$ See Backus, Kehoe, and Kydland (1994) and Monacelli and Perotti (2010) for an analysis within the real business cycle and the new Keynesian model, respectively. In the Keynesian textbook experiment, in turn, government spending raises domestic interest rates, triggering capital inflows and an appreciation of the currency. An exception is the model developed by Obstfeld and Rogoff (1995) which predicts that government spending depreciates the (nominal) exchange rate because of fiscal-monetary interactions: households lower their consumption and, hence, their money demand in response to increased government spending. If the money supply is held constant, the currency must depreciate in nominal terms.

${ }^{7}$ Aside from the exchange rate regime, trade openness is another variable with potentially significant implications for fiscal policy transmission. Specifically, a well-known argument suggests that greater trade integration weakens the effectiveness of fiscal stimulus, insofar as it reduces households' and firms' marginal propensity to spend on domestic goods: with a larger fraction of income spent on imports, more of the fiscal stimulus "leaks" abroad. Erceg, Gust, and López-Salido (2010) provide a quantitative analysis using a modern business cycle model. In the present paper we do not explore the role of trade openness, because in our data set more open countries (in terms of import shares) systematically tend to be small economies with pegged exchange rates, complicating the identification of any distinct openness effects. We leave an analysis of this dimension to future work drawing on a larger data set.
} 
comovement accords well with the neoclassical account of fiscal transmission, it was widely perceived as puzzling in the light of (Keynesian) received wisdom. Subsequently, a small strand of the literature has identified aspects of an economy's public finances that can alter the private consumption response to fiscal measures. Starting from the observation that fiscal consolidations are typically undertaken at exceptionally high levels of public debt, Bertola and Drazen (1993) propose a neoclassical model where the correlation between private and public consumption changes as debt approaches some critical level known to trigger a sharp fiscal retrenchment. ${ }^{8}$

Perotti (1999) derives a similar prediction from a model with a Keynesian bend. The model economy is populated not only by unconstrained households who internalize the government budget constraint, but also by some credit-constrained households who consume their entire disposable income in each period. Taxes are distortionary, and the economy is assumed to be initially away from the optimal tax smoothing path. In this model, the response of aggregate demand to fiscal measures depends on the initial level of debt. In "good" times, fiscal balances and private consumption comove negatively; in "bad" times, with high levels of public debt, the comovement becomes positive. Intuitively, if initial debt is high, the distortions from a further increase in tax rates are large, amplifying the negative wealth effect experienced by unconstrained households to the point that it outweighs any positive effect of the fiscal expansion on the income and consumption of constrained households.

To take this model to the data, Perotti (1999) adopts a two-step econometric procedure, similar to the approach we pursue in this paper. In a first step, he estimates a near-VAR model on annual data for 19 OECD countries, which he uses to identify fiscal policy shocks. In a second step, he regresses consumption growth on the fiscal shocks obtained from the first regression, as well as an interaction term of this shock with a dummy capturing "bad times." The bad-times dummy is constructed based on the level of debt and the budget deficit. Consistent with Perotti's theory, consumption responds positively to government spending increases and tax cuts in normal times, but the sign of the response changes in bad times. ${ }^{9}$

\subsection{Financial crises}

A distinguishing feature of financial crises is that access to credit becomes severely restricted. Although not intended as a model of fiscal transmission during financial crisis, the work of Galí et al. (2007) provides a useful starting point to think about this interaction. The authors extend the standard new Keynesian model to include a fraction of "constrained" households who, as in Perotti (1999), do not participate in asset markets and therefore consume their disposable income in each

\footnotetext{
${ }^{8}$ In a related study, Sutherland (1997) focuses on tax policy in an overlapping generations framework and finds that tax cuts may have contractionary effects if debt is high and current generations of consumers expect consolidation to take place during their lifetime.

${ }^{9}$ In a recent study, Afonso and Jalles (2011) condition the effects of fiscal consolidations on the level of public debt. They find that a reduction in government consumption tends to raise private consumption if public debt is high.
} 
period. A large weight of these households in the overall population reinforces the expansionary effects of fiscal policy, since their demand moves in proportion to any increase in employment and wages brought about by additional public demand. ${ }^{10}$ To the extent that a financial crisis raises the share of credit-constrained agents, the model implies a corresponding increase in the size of the fiscal multiplier. ${ }^{11}$ Moreover, as the analysis of Corsetti et al. (2011a) shows, credit constraints have a larger effect on the multiplier under a regime of fixed exchange rates or in a monetary union.

Aside from intensifying credit constraints, financial crises can have another important effect, as exemplified by the most recent experience of global financial turmoil since 2007. Specifically, a financial crisis may cause such a pronounced recessionary impact that monetary policy winds up at the zero lower bound on policy rates, impairing the central bank's ability to further stimulate the economy. As the recession takes hold, a vicious circle may set in: weak demand causes firms to cut prices; if pricing decisions are staggered, falling prices generate expectations of lasting deflation; for a given nominal interest rate, this translates into higher real rates, which further weaken demand, thus reinforcing the deflationary dynamics; see, for example, Eggertsson and Woodford (2003). ${ }^{12}$ Under these circumstances, fiscal stimulus can become a powerful tool to halt the deflationary dynamics, as higher government spending is fully accommodated through an unchanged (zero) policy rate. Indeed, Christiano et al. (2011) derive fiscal multipliers on output which exceed two or even three; see also Hall (2009), Erceg and Lindé (2010), or Woodford (2011). ${ }^{13}$

\section{Empirical strategy}

In this section, we introduce the empirical strategy we use to assess the role of the economic environment for the transmission of fiscal policy shocks. Before providing details about each of the two steps required by our estimation method, we discuss how our identification strategy relates to alternative approaches in the literature. We conclude this section with a brief description of our data set.

\subsection{Identification issues}

Most of the existing empirical work on fiscal policy transmission employs structural VAR models to gauge the impact of spending shocks on the economy. Following the lead of Blanchard and Perotti

\footnotetext{
${ }^{10}$ Bilbiie, Meier, and Müller (2008) use a similar framework to match the time-series evidence on U.S. fiscal transmission, explicitly linking household consumption to asset market participation.

${ }^{11}$ In the same vein, Fernández-Villaverde (2010) explores fiscal transmission in the presence of financial frictions which constrain firms' investment, thereby linking public demand to entrepreneurs' net wealth.

${ }^{12}$ These dynamics would be less pronounced to the extent that central banks can further loosen monetary conditions using unconventional policy tools, such as purchases of long-term assets. It is doubtful, however, whether central banks are prepared and able in practice to impart any desired level of additional stimulus through such tools.

${ }^{13}$ However, the introduction of sovereign risk premia may alter these results, as higher public deficits adversely affect funding costs in the wider economy; see Corsetti et al. (2012).
} 
(2002), several authors have based identification on the assumption that discretionary government spending is subject to certain decision and/or implementation lags that prevent policymakers from responding to contemporaneous developments. ${ }^{14}$ According to this idea, significant parts of government spending are determined by past information only. Government consumption and investment, in particular, are likely to be unresponsive to current economic conditions, as (unlike transfers) they normally contain no automatic cyclical component. ${ }^{15}$ Below we provide a more detailed discussion of this identifying assumption and its relation to the frequency of fiscal data.

An alternative estimation strategy is suggested by Ramey and Shapiro (1998), who consider a small number of events in postwar U.S. fiscal policy, including the military build-up for the Korean and Vietnam wars, that were arguably exogenous (with respect to economic conditions) and thus provide natural experiments for the effect of a sudden surge in government spending. Subsequent studies have used this approach within a VAR context; see Edelberg, Eichenbaum, and Fischer (1999), Burnside, Eichenbaum, and Fisher (2004), and Ramey (2011). The latter study also considers a richer data set of military events ${ }^{16}$ and an alternative identification strategy using forecast errors compiled on the basis of surveys of professional forecasters. Ramey (2011) highlights differences between her results and those obtained under the Blanchard-Perotti identification scheme and argues that they are likely to reflect the wrong timing of shocks under the Blanchard-Perotti approach. Specifically, the government spending shock picked up by the econometrician may well have been anticipated by economic agents. Thus, the adjustment may already be underway by the time the shock is diagnosed. Finally, Mountford and Uhlig (2009) have put forward an identification scheme based on sign restrictions: government spending shocks are identified within estimated VAR models by imposing the sign of the response of certain variables for which theoretical predictions are fairly uncontroversial. While Mountford and Uhlig (2009) focus on domestic variables, Enders, Müller, and Scholl (2011) derive sign restrictions on the basis of a richly specified open economy business cycle model, in order to analyze the international transmission of government spending shocks.

For the purposes of the empirical interest pursued in this paper, none of the above estimation

\footnotetext{
${ }^{14}$ Recent contributions include Perotti $(2004,2007)$ and Galí et al. (2007), which focus on domestic-economy variables, and Canzoneri, Cumby, and Diba (2003), Kim and Roubini (2008), and Corsetti and Müller (2006), which address the international dimension. In an early contribution Rotemberg and Woodford (1992) estimate the impulse responses to a change in military spending using a VAR model on U.S. data.

${ }^{15}$ One possible exception is the indexation of government wages, which would lead to higher nominal outlays during times of strong economic activity and inflation. If budgets are fixed in nominal terms, real government spending would fall in this case. Previous work has, however, found such inflation-related cyclicality to be of very limited quantitative importance in advanced economies; see Perotti (2004).

${ }^{16} \mathrm{~A}$ related strand of the literature has focused squarely on the multiplier for defense spending, by regressing output growth on the change in government spending and possibly some additional control variables. Identification rests again on the assumption that military spending is largely unresponsive to the state of the economy; see Barro and Redlick (2011) and Hall (2009) for recent contributions along these lines. An important caveat is that military expenditure might rise systematically with command-type interventions in the economy, thus causing a downward bias in the estimated multiplier; see Hall (2009). More generally, it is unclear whether the estimated macroeconomic effects of higher military expenditure can readily be extrapolated to other types of government spending.
} 
strategies offers sufficient flexibility. Irrespective of the specific identification scheme, the simple linear structure of standard VARs severely constrains any analysis of conditional dynamics in fiscal policy transmission. The most VAR studies allow for is to examine differences in transmission across a small number of distinct subsets of the data, through appropriate sample splits. Ilzetzki et al. (2011), for instance, estimate panel VARs for different subgroups of countries distinguished by income, the level of foreign debt, the exchange rate regime, openness, and the degree of capacity utilization. ${ }^{17}$ In order to preserve sufficiently large data sets, however, the authors cannot isolate the importance of more than one such dimension at a time. In addition, it is difficult to account for time-varying attributes, such as presence of a financial crisis, within the framework developed by Ilzetzki et al. (2011). Hence their work, while closely related and complementary to ours, leaves open the question about the marginal importance of specific country characteristics for fiscal policy transmission. At the same time, the panel VAR setup imposes significant homogeneity on the structure of fiscal policymaking across countries in a given subset of the data. Ramey and Shapiro's “event" approach, in turn, is constrained by the shortage of episodes with clear-cut exogenous fiscal policy shocks, especially once the analysis is extended beyond the United States. ${ }^{18}$

In this paper, therefore, we pursue a two-stage estimation strategy similar to the one proposed by Perotti (1999). In the first step, we estimate a fiscal policy rule that is meant to describe the statistical process of government spending and provide estimates of spending shocks. The fiscal policy rule we consider links government spending to important macroeconomic aggregates. It is thus quite similar to the structure embedded in fiscal policy VARs. We estimate these fiscal policy rules for one country at a time, thus allowing for significant heterogeneity in national policymaking. In the second step, we use the estimated policy shocks as a regressor to trace the impact of government spending on key macroeconomic variables, including output, private consumption and investment, the trade balance, and the real effective exchange rate. ${ }^{19}$ A flexible specification is chosen to account for the effects of spending shocks in different economic environments, that is, under pegged vs. flexible exchange rates, with sound vs. strained fiscal positions, and during normal times vs. times of financial crisis.

\subsection{The first step: Identifying government spending shocks}

The first step consists in estimating an annual time series of fiscal policy innovations for each country $i$ in the sample. As our policy variable of interest, we consider per capita government consumption expressed in logs. Government consumption is sizeable: it accounts for a significant 21.5 percent

\footnotetext{
${ }^{17}$ See also Beetsma, Giuliodori, and Klaasen (2008) for a distinction of countries by openness within a European sample.

${ }^{18}$ More recently, the literature has exploited variation in spending at the subnational level to estimate multipliers controlling for monetary policy and, when possible, budget adjustment policy, depending on the budget rules of fiscal federalism; see Acconcia, Corsetti, and Simonelli (2011) and Corsetti et al. (2011a) for a theoretical model.

${ }^{19}$ This procedure is asymptotically equivalent to the standard VAR approach; see Christiano, Eichenbaum, and Evans (1996).
} 
of GDP in the average country in our sample. More important, it is held to contain virtually no automatic cyclical component, facilitating the attempt to identify government spending changes above and beyond systematic fluctuation over the cycle. Unlike public investment, government consumption also has no obvious direct link to private sector productivity, limiting the number of possible channels through which fiscal policy affects the real economy.

We assume that the process of government spending is described by a relatively simple rule that relates our fiscal variable of interest $\left(g_{t}\right)$ to its own first and second lag, the first two lags of log per capita output $\left(y_{t-1}\right.$ and $\left.y_{t-2}\right)$, the lagged value of a composite leading indicator $\left(c i_{t-1}\right.$, which proxies directly for the authorities' pre-budget expectations with respect to next-year growth), and the beginning-of-period debt stock, expressed as a share of GDP $\left(b_{t-1}\right)$. The specification also includes a trend variable and a constant. Finally, our interest in the conditional dynamics of fiscal policy motivates us to include (in most specifications) a set of dummy variables capturing key features of the economic environment, i.e., dummies indicating an exchange rate peg ( peg $\left._{t-1}\right)$, strained public finances $\left(\operatorname{strain}_{t}\right)$, and a financial crisis $\left(f c_{t-1}\right)$. Note that the information captured by each of the three dummies is lagged by one period, consistent with our general identifying assumption. In the case of the fiscal strain dummy, this is achieved by defining a period of fiscal strain as a function of high beginning-of-period debt and/or a high deficit in the preceding year. The resulting equation reads as follows:

$$
\begin{aligned}
g_{t, i} & =\phi_{i}+\eta_{i} \operatorname{trend}_{t}+\beta_{i, 1} g_{t-1, i}+\beta_{i, 2} g_{t-2, i}+\gamma_{i, 1} y_{t-1, i}+\gamma_{i, 2} y_{t-2, i}+\theta_{i} \operatorname{cli}_{t-1, i}+\delta_{i} b_{t-1, i} \\
& +\rho_{i, 1} \text { peg }_{t-1, i}+\rho_{i, 2} \operatorname{strain}_{t, i}+\rho_{i, 3} \text { crisis }_{t-1, i}+\varepsilon_{t, i} .
\end{aligned}
$$

The rule posits stable parameters $\left(\phi_{i}, \eta_{i}, \beta_{i}, \gamma_{i}, \theta_{i}, \delta_{i}\right.$, and $\left.\rho_{i}\right)$ over time for each country in the sample, but allows the parameters to differ across countries. ${ }^{20}$ The additive shock term $\left(\varepsilon_{t, i}\right)$ is meant to capture unexpected discretionary policy changes, whose impact on the real economy is the ultimate object of our study. Note that the policy rule also allows for the desirable property of automatic debt stabilization, namely when $\delta_{i}<0 .{ }^{21}$

The key assumption, however, relates to the contemporaneous relationship between government spending and its determinants, notably output. Identification requires that there be no two-way contemporaneous interdependence. This is achieved by assuming that spending cannot respond to simultaneous output developments. ${ }^{22}$ Instead, spending is assumed to respond to past growth developments as well as expectations about economic activity formed one period in advance.

\footnotetext{
${ }^{20}$ Since equation (1) constitutes a univariate regression (rather than the by now frequently applied VAR model), it is useful to keep in mind that the inclusion of lagged variables addresses concerns about spurious regression results; see chapter 18.3 of Hamilton (1994).

${ }^{21}$ Corsetti et al. (2011b) study the impact of debt-responsive government spending on fiscal multipliers and provide evidence for spending reversals in U.S. fiscal data.

${ }^{22}$ This assumption carries over to the effect of economic environment variables on fiscal policy choices, as signaled by the use of lagged-information dummies in the policy equation.
} 
Specifically, we include the normalized value of the OECD's composite leading indicator (CLI) from October of the previous year as a proxy for growth expectations held around the time of budget formulation. The CLI is a real-time measure with a track record of predicting changes in economic activity, especially cyclical turning points, several months in advance. As such, it seems well suited to capture expectations about the growth outlook held by policymakers and the public. ${ }^{23}$

In principle, our identifying assumption could be violated for two reasons. First, fiscal policy in most countries contains nondiscretionary cyclical elements, or automatic stabilizers. For our study, however, these automatic stabilizers should not pose a problem, as they operate essentially through (tax) revenue and transfer payments, such as unemployment benefits, but not through higher or lower outlays for government consumption.

A second potential problem is discretionary fiscal policy action in response to contemporaneous output developments. The relevance of this concern obviously hinges on the precise definition of "contemporaneous". Blanchard and Perotti (2002), for instance, argue that government spending policy cannot typically respond to output shocks within the same quarter. Indeed, fiscal authorities are subject not only to constraints on data availability about real-time developments but also to usually significant time lags between budget formulation and execution. Whether or not these constraints prevent discretionary policy responses for more than one quarter, is an open question. In most countries the official timetable for the budget process typically follows the calendar, implying that the main discretionary measures to be implemented in any given year are discussed and adopted at the end of the previous year, based on economic forecasts. Supplements throughout the year are nevertheless possible; see Perotti (2004).

Yet it is actually possible to test whether annual government spending is predetermined conditional on being predetermined at the quarterly frequency, at least for countries that publish high-quality quarterly fiscal data. Born and Müller (2012) perform such tests on data for the United States, United Kingdom, Canada, and Australia up to 2007Q4. Their main result is that the restriction that government spending does not respond to other variables in the VAR within a year cannot be rejected. In fact, the impulse responses obtained under this restriction are virtually identical to those obtained under the conventional Blanchard-Perotti identification assumption. Beetsma, Giuliodori, and Klaassen (2009) perform an alternative test and reach the same conclusion.

Notwithstanding this systematic evidence, the fiscal stimulus packages adopted by the U.S. Congress in early 2008 and 2009 may suggest that the time lag between the arrival of new economic data and the implementation of a fiscal response can be shortened to about 5-8 months, at least under exceptional circumstances. However, it should be stressed in this context that the swiftest element in U.S. policymakers' response to the unfolding crisis—in both decision-making and implementation-

\footnotetext{
${ }^{23}$ For our estimation, like most authors, we rely on final rather than real-time data. Given the sometimes significant revisions to real-time data, this raises conceptual challenges for the interpretation of policy shocks; see Cimadomo (2011).
} 
was a set of tax rebates, which would not be included in our concept of government spending. ${ }^{24}$ With these caveats in mind, it is worth noting that the Blanchard-Perotti identification has been previously employed on annual data by several authors, including Beetsma, Giuliodori, and Klaasen (2006) and Bénétrix and Lane (2009). In part, this may simply reflect practical constraints, as reliable quarterly fiscal data are not readily available for more than a handful of advanced economies. In part, it reflects the sense that quick-response fiscal policy is a very rare exception, and perhaps mostly focused on tax measures. Indeed, the above-mentioned U.S. stimulus packages were closely related to the very exceptional circumstances created by the global financial crisis. In order to capture the unusual dynamics of fiscal policy during such exceptional times, we include a lagged financial crisis dummy in the specification above. Given the start date of the financial crisis in 2007, the dummy should adequately capture any systematic fiscal policy response to the crisis during 2008-09, when the two consecutive stimulus packages were agreed. In addition, we perform a sensitivity analysis where we limit our sample period to include data only up to 2006. We find that our results are robust with respect to this variation of the sample period.

Aside from these considerations, there is another more substantive argument for using annual data even if they might at times give rise to endogeneity issues under the Blanchard-Perotti identification strategy. Indeed, using annual data is likely to attenuate a separate possible concern about identification, namely that identified spending shocks might be foreseeable. The U.S. stimulus packages in 2008-09 again provide a case in point. The tax rebate measures announced in January 2008 , for instance, were only starting to be implemented toward the end of the second quarter of 2008. Treating the measure as an unanticipated shock in the second and third quarter would therefore be incorrect, possibly inducing a severe bias in estimates of its effect on the real economy. The same is true for the extra spending legislated in the early 2009 stimulus package, which only started coming on stream several months later. This anticipation problem has gained prominence through the recent work of Mountford and Uhlig (2009) and Ramey (2011). Although the issue is likely to affect fiscal policy studies in general, it is arguably a greater concern for high-frequency (such as quarterly) data. Note, finally, that policy rules similar to (1) have been considered in a range of recent quantitative studies of fiscal policy. One example of a single-estimation approach like ours is Galí and Perotti (2003). However, equation (1) also mimics many of the government spending equations contained in VAR-based studies, such as Blanchard and Perotti (2002). Although relatively simple, these rules appear to capture quite well the macroeconomic essence of fiscal policy, thus providing us with useful measures of fiscal policy innovations.

\footnotetext{
${ }^{24}$ Spending cuts might also be implemented swiftly during episodes of intense fiscal consolidation, especially when governments are forced to tighten the budget in response to falling output.
} 


\subsection{The second step: Tracing the effects of government spending in different economic environments}

In the second step, we use the estimated fiscal shocks $\left(\widehat{\varepsilon}_{t, i}\right)$ to gauge the dynamic impact of government spending on aggregate output, its key components, as well as international prices. We begin this exercise by describing the economy's average, or unconditional, response to a spending shock, abstracting from the role of specific economic environments. Subsequently, however, we allow the response to be affected by the set of conditioning factors introduced above, namely exchange rate regimes, the state of public finances, and financial crises. Accordingly, we specify the following prototype second-step equation, to be estimated in a fixed-effects panel regression:

$$
\begin{aligned}
x_{t, i} & =\alpha_{i}+\mu_{i} \operatorname{trend}_{t}+\chi_{i} x_{t-1, i}+\sigma_{1} \widehat{\varepsilon}_{t, i}+\sigma_{2} \widehat{\varepsilon}_{t-1, i}+\sigma_{3} \widehat{\varepsilon}_{t-2, i}+\sigma_{4} \widehat{\varepsilon}_{t-3, i} \\
& +\kappa_{1}\left(\widehat{\varepsilon}_{t, i} * d_{t, i}\right)+\kappa_{2}\left(\widehat{\varepsilon}_{t-1, i} * d_{t-1, i}\right)+\kappa_{3}\left(\widehat{\varepsilon}_{t-2, i} * d_{t-2, i}\right)+\kappa_{4}\left(\widehat{\varepsilon}_{t-3, i} * d_{t-3, i}\right) \\
& +\lambda_{1} d_{t, i}+\lambda_{2} d_{t-1, i}+\lambda_{3} d_{t-2, i}+\lambda_{4} d_{t-3, i}+u_{t, i}
\end{aligned}
$$

where $x_{t, i}$ denotes one of our macroeconomic variables of interest (e.g., consumption); $d_{t, i}$ is a dummy variable indicating a certain feature of the economic environment in a particular year, such as a currency peg or a financial crisis; and $\sigma$ and $\kappa$ are the key parameters of interest. Specifically, for $d_{t, i}$ indexing a currency peg, the $\sigma$ parameters capture the dynamic effect (up to three years after the impact) of a government spending shock in economies with a floating currency, while the $\kappa$ parameters indicate the additional marginal effect of the spending shock under a peg. Lastly, the $\lambda$ parameters account for the direct effect of that same economic feature.

Apart from the relevant set of interaction and dummy terms, we also include further control variables in our specifications, notably the lagged dependent variable and a trend, each with country-specific coefficients. Controlling for such additional variables is not strictly required: provided that our firststep identification strategy delivers accurate estimates of fiscal policy shocks, these innovations are orthogonal to all other contemporaneous information, thus assuring consistent second-step estimates. For all of the specifications using standard fixed-effects panel estimation, we report GMM-based standard errors that correct for the inclusion of generated regressors, i.e., the government spending shocks estimated in the first step; see Newey and McFadden (1994).

\subsection{The data}

As foreshadowed above, we consider annual data, covering a maximum period from 1975 through 2008, although for robustness we also consider a shorter sample that excludes the recent global financial crisis. We aim to include the same 19 OECD countries studied by Perotti (1999), but due to data limitations (we require at least 20 consecutive annual observations to obtain reliable estimates for the fiscal policy rule in the first step) wind up with a sample of 17 countries: Australia, Austria, 
Belgium, Canada, Denmark, Finland, France, Ireland, Italy, Japan, Netherlands, Norway, Portugal, Spain, Sweden, the United Kingdom, and the United States. Table 1 provides further details.

The variables used in our estimation are detailed in Table 2. Our primary data sources are the IMF and OECD. The real exchange rate as well as most expenditure aggregates are expressed in logs; the trade balance is expressed in percentage points of GDP; and inflation and the nominal interest rate are expressed in percent. As regards our dummies, the classification of exchange rate regimes is based on Ilzetzki et al. (2009), while the financial crisis dates are provided by Reinhart and Rogoff (2008) and Reinhart (2010). Our definition of weak public finances requires government debt in excess of 100 percent of GDP or net government borrowing above 6 percent of GDP (each lagged once). These definitions are varied below to verify the robustness of our findings.

\section{Systematic and non-systematic changes in government spending}

The primary focus of our study is on the economy's response to government spending shocks, i.e., changes in government spending that are not systematically related to the state of the economy. We estimate these responses in the second step of our estimation strategy. Nevertheless, the results obtained for the first step are also of interest in their own right, insofar as they capture the systematic response of government spending to the state of the economy. For example, estimates of the parameters for the empirical fiscal rule can shed some light on whether and how spending policy responds to cyclical developments, on the one hand, and debt levels, on the other.

Table 3 provides a summary of results from the first-step estimation of the spending rule for each country included in our sample. A few observations stand out. To start with, the fit obtained by our simple empirical fiscal rule is very high, reflecting the inclusion of autoregressive terms in our specification for log levels. Nonetheless, the fit remains quite good for most countries even when we re-estimate the model in growth rates, as we do for one of our robustness checks.

Turning to the parameter estimates, the most general qualitative finding is for government spending to respond negatively to the outstanding stock of public debt. The corresponding coefficient is estimated to be negative for all but three countries (Austria, Finland, and the United Kingdom), and significantly so for about half of them. This finding aligns well with the argument that government spending has a greater role to play in debt consolidation strategies than standard theoretical models assume-a point analyzed in detail by Corsetti et al. (2011b). The estimates of the coefficients on lagged output and the composite leading indicator are somewhat harder to translate into a clear statement about the cyclical properties of government spending. In particular, the relevant coefficients should not be regarded in isolation, as the other two related coefficients capture the cyclical properties of spending as well.

Another result worth noting relates to the sign of the estimated financial crisis dummy for those countries where financial crises occurred during the sample period. Counter to the experience from 
stimulus policies in advanced countries during the most recent crisis, the relevant coefficient is estimated to be negative, and sometimes significantly so, in nine out of thirteen countries. This implies that government spending would slow down, rather than accelerate, during financial crises (holding everything else fixed). While perhaps surprising, this points to the fact that what has been considered desirable during the latest global financial crisis of 2008-09, i.e., disproportionately strong countercyclical fiscal stimulus, is not necessarily what countries have found opportune during previous crises. A key reason for this may be concerns about financing constraints, especially when banking sector bailouts and falling tax revenue already put a significant dent into the public finances. Next, we turn to the primary output of interest provided by the first-step regression, i.e., the estimated fiscal policy shocks. Although our choice of an empirical policy rule is motivated by theoretical considerations and previous contributions in the literature, its appropriateness needs to pass statistical tests, too. Specifically, if the residuals are supposed to be reliable measures of unanticipated spending changes, one obvious requirement is that they exhibit no serial correlation. We test for this property using Arellano-Bond tests for autoregression (at one, two, and three lags) for each of the countryspecific residual series in our sample. As the last column of Table 3 shows, the null hypothesis of no autocorrelation cannot be rejected at conventional levels for any of the countries.

Additional information on the shock series retained for the second-stage estimation is provided in the right column of Table 1 and in Table 4. Table 1 describes the composition of the final sample. It is somewhat reduced from the initial sample, now comprising 444 country-year observations. This reflects data gaps for some of the variables included in the second-stage regressions. For example, whenever a country's exchange rate regime changed within a given year, that observation is deleted from the sample, implying a gap for each country-year observation that requires this data point as a contemporaneous or lagged regressor in the second step.

The shocks contained in the final sample exhibit a mean and median close to zero and a standard deviation of 1.02 percent of government spending. The minimum and maximum values, ranging from -3.57 to 5.16 percentage points, are also indicated in Table 4. Finally, the correlation of the estimated shocks with the raw growth rate of government spending is 0.64 . This suggests that the first-step estimation clearly removes some systematic component of government spending changes, while producing a shock series that still bears a resemblance with the raw data, facilitating an intuitive interpretation of the identified fiscal innovations. ${ }^{25}$

\footnotetext{
${ }^{25}$ Interpreting the shocks is subject to the caveat stressed by Sims (1998).
} 


\section{The effects of government spending shocks}

As detailed in the previous sections, our model is meant to capture the dynamic response of key macroeconomic variables to a government spending shock. Specifically, we consider the responses of eight variables of interest: output and its components (private consumption, private fixed investment, and the trade balance), the real effective exchange rate, CPI inflation, the short-term nominal interest rate, and, of course, government spending itself. While our second-step regression for expenditure aggregates is specified in log levels (or the ratio to GDP in the case of the trade balance), we transform the results so as to allow a simple interpretation in terms of percentage points of GDP. The behavior of each variable is traced for six years after the impact.

\subsection{Unconditional effects}

Although our primary objective is to analyze the economy's response to a spending shock conditional on different economic environments, it is useful to begin our analysis by presenting unconditional estimates, i.e., those obtained without regard for any differences across environments. In the relevant regressions for both the first and the second step, we thus omit all of the economic environment dummies listed in Table 5. ${ }^{26}$ The unconditional estimates not only provide a benchmark against which to assess the main contribution of our paper, but also allow us to verify that our two-step procedure produces average results similar to those typically reported in the literature. Figure 1 provides a graphical representation of the results in terms of impulse response functions. The solid lines indicate the point estimate, while the shaded areas represent one-standard-deviation confidence intervals. ${ }^{27}$ The horizontal axis measures the time after the shock in years, the vertical axis measures deviations from trend. GDP and its components are measured in output units, while the real exchange rate is measured in percent; the interest rate and inflation are measured in percentage points. We normalize impulse responses so that the initial increase in government spending is one percent of GDP under the baseline scenario defined below. ${ }^{28}$

As shown in the first row of Figure 1, we find a persistent increase in government spending and a sizeable increase in aggregate output by about 0.7 percentage points on impact, whereas consumption does not respond at all. As the responses of output and consumption are measured in the same units

\footnotetext{
${ }^{26}$ To conserve space, we do not report the results from the first-stage estimation for this more parsimonious specification. The results are in line with those shown in Table 3. In particular, government spending exhibits no clear cyclical pattern, but responds negatively to the level of public debt.

${ }^{27}$ We compute standard errors by drawing 1,000 realizations of the coefficient vector assuming a multivariate normal distribution with variance-covariance matrix corresponding to that of the regression coefficients; the mean is set equal to the point estimate.

${ }^{28}$ Typically, this requires considering an estimated shock slightly greater than one percent of GDP, as the point estimate of the response of government spending to the standardized shock tends to be around 0.9 only. This probably reflects a moderate attenuating bias in the second step caused by measurement error in the first step. In order to express GDP and its components in output units we use the average expenditure shares in our sample period.
} 
Government spending

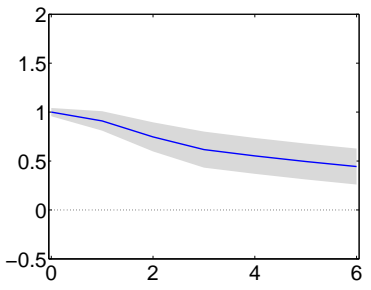

Net exports

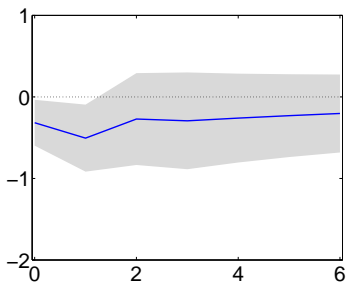

Output

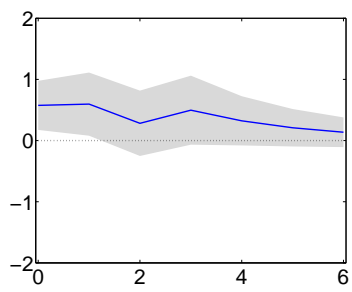

Real exchange rate

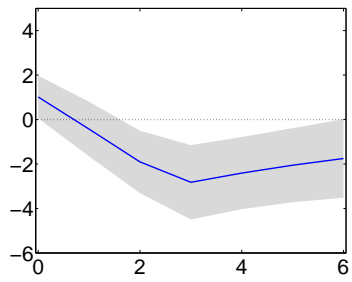

Consumption

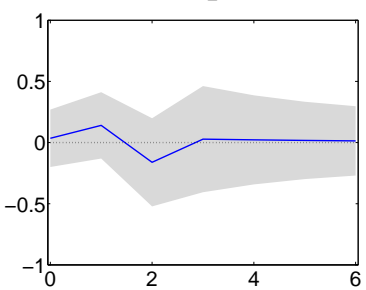

Inflation

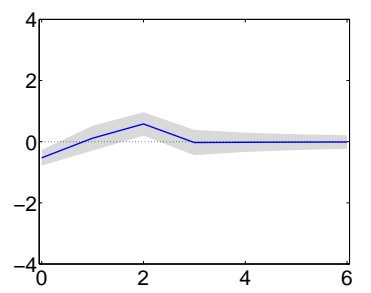

Investment

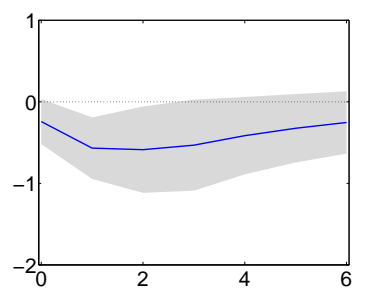

Interest rate

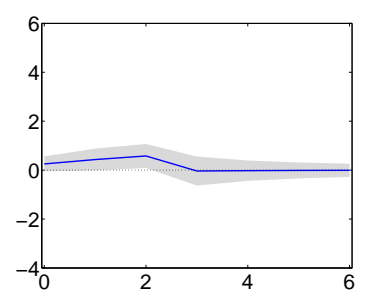

Figure 1: Impulse responses to government spending shock: unconditional effects. Notes: quantities measured in output units; solid line: point estimate (shaded area: \pm one standard error).

as government spending, the responses represent estimates of the government spending multipliers on output and consumption, respectively.

Our results for the average multipliers are well within the range of results reported in the literature. ${ }^{29}$ As recently summarized by Hall (2009), "empirical work using simple regressions or more elaborate VARs finds output multipliers in the range from 0.5 to 1.0 , with a few exceptions, and consumption multipliers in the range from somewhat negative to 0.5." As regards the consumption multiplier, for instance, studies adopting the Blanchard-Perotti identification typically report a positive estimate, although more recent evidence based on this approach suggests a decline in the multiplier over time; see Perotti (2004) and Bilbiie et al. (2008). Studies drawing on the Ramey-Shapiro approach, in turn, often report a negative multiplier for consumption, but the effect is typically quite contained in quantitative terms. Lastly, while using different identification strategies, neither Mountford and Uhlig (2009) nor Barro and Redlick (2011) or Hall (2009) find a significant response of consumption to a deficit-financed government spending shock or an increase in defense spending, respectively.

Turning to the last panel of the first row of Figure 1, we find that government spending reduces private investment. A fall in investment is a clear-cut result documented in various studies, including Blanchard and Perotti (2002), Mountford and Uhlig (2009), and Ramey (2011). The estimated response of the trade balance suggests that a positive spending shock also triggers a decline in net exports. This again squares well with conventional wisdom and earlier empirical studies, supporting

\footnotetext{
${ }^{29}$ Note that we measure the absolute response of the variable of interest in percent of output, given an initial increase of government spending by one percent of GDP. An alternative measure of the multiplier divides the cumulative response of the variable of interest by the cumulative response of government spending, as the latter responds endogenously to the shock. For our results below, we obtain very similar results, notably regarding the effect of the economic environment, if we compute cumulative multipliers.
} 
the notion of "twin deficits," defined as a conditional positive correlation between budget and current account deficits. For the United States, however, Kim and Roubini (2008) find that, in response to fiscal shocks, the trade balance and the government budget actually move in opposite directions, a phenomenon the authors dub "twin divergence." Subsequent work by Corsetti and Müller (2006) and Monacelli and Perotti (2010) extends the analysis to countries other than the United States. Overall, it appears that expansionary fiscal measures worsen the trade balance, though not strongly so. In this regard, our estimation methodology may help shed light on whether there is any systematic pattern linking "twin deficits" or "twin divergence" to particular features of the economy.

The second row of Figure 1 also displays the responses of inflation, the short-term nominal interest rate, and the real exchange rate. Inflation drops on impact, but then rises temporarily above baseline. The short-term decline in inflation after an increase of government spending is surprising in light of predictions of standard theoretical models. However, it has been documented under various alternative identification schemes; see Perotti (2004) and Mountford and Uhlig (2009). The shortterm interest rate, in turn, rises on impact and then moves in tandem with inflation. Finally, the real effective exchange rate appreciates slightly on impact, but then depreciates over time. While the initial appreciation conforms well with conventional wisdom, it contrasts with the evidence from a few recent studies which document a fall in the real exchange rate after a rise in government spending. ${ }^{30}$ However, the studies reaching this conclusion typically focus on countries featuring flexible exchange rate regimes. In contrast, studies focusing on euro area countries tend to document real appreciation in response to positive spending shocks. ${ }^{31}$ These contrasting findings suggest that the dynamic response of the real exchange rate may differ systematically across currency regimes. Our methodology is again well suited to examine this issue more closely.

Indeed, the premise of our study is that findings based on simple unconditional models may conceal large differences in the response to fiscal shocks across economic environments. ${ }^{32}$ With this in mind, we turn next to the results for our full second-step specification, which accounts simultaneously for several dimensions of the economic environment.

\subsection{Accounting for the economic environment}

The three dimensions of the economic environment which we argue are likely to have a bearing on government spending multipliers include the exchange rate regime, the state of public finances, and the health of the financial sector. While the definitions of these characteristics are provided in Table 2, Table 5 gives a summary of which country-year observations fit under each of these categories. We

\footnotetext{
${ }^{30}$ Kim and Roubini (2008) and Enders et al. (2011), for instance, report a depreciation of the REER for the United States. Monacelli and Perotti (2010) find a depreciation for Australia, the United States, and the United Kingdom.

${ }^{31}$ See, for example, Beetsma et al. (2008) and Bénétrix and Lane (2009).

${ }^{32}$ Further support for this point comes from the finding of Perotti (2004) that the effects of government spending on the economy tend to be more muted after 1980 in the United States.
} 
thus estimate equation (2) for our entire final sample, including all relevant interaction terms.

Figures 2 to 4 represent the results graphically. For each dimension of the economic environment, we report impulse responses for all variables of interest, comparing dynamics relative to a common baseline scenario. Although this focuses the discussion on only one conditioning factor at a time, it is worth stressing that the results pertain to a comprehensive specification that simultaneously controls for all three dimensions we are interested in. This is important insofar as variations along these dimensions are not necessarily orthogonal to each other. For the purposes of our charts, we condition on an identical environment in the two dimensions that are not the focus of the respective chart.

Baseline scenario: flexible exchange rate, sound public finances, no financial crisis. In Figures 2 through 4 , we report results for the marginal effects of a government spending shock for a baseline scenario defined by an economy that does not peg its currency, is characterized by relatively sound public finances (debt below 100 percent of GDP and lagged net borrowing below 6 percent of GDP), and does not experience a financial crisis. In each figure, the impulse responses for this baseline scenario are denoted by a solid line, the confidence intervals by shaded areas. We find the response of output to be essentially zero in this case; there is mild crowding out of consumption, and pronounced crowding out of private investment. Compared to the unconditional findings discussed above, these results support the notion that, in an economy with flexible exchange rates in normal times, the macroeconomic effects of a government spending expansion are generally weak. In contrast to the unconditional findings shown in Figure 1, the response of net exports is no longer negative. This contradicts conventional wisdom, but is more in line with the evidence reported for the United States by Kim and Roubini (2008).

Observe further that inflation falls on impact, but rises visibly over time. Still, monetary policy remains quite accommodative: the response of the short-term interest rate is actually negative both on impact and for some quarters thereafter. Correspondingly, the real exchange rate depreciation is more pronounced and persistent than in Figure 1, sharpening the contrast with the conventional wisdom. As discussed above, this finding matches a growing body of evidence, but calls into question the transmission mechanism of many theoretical models. Specifically, conventional wisdom holds that government spending causes real appreciation and thus decreases net exports, implying a muted overall output response. Our empirical results are at odds with such a view. While output is essentially flat, net exports do not deteriorate, and the real exchange rate depreciates. From a theoretical point of view, it is important to stress that the conventional wisdom relies on specific assumptions about the stance of monetary policy that are typically left implicit. At the same time, several recent VAR studies on the basis of U.S. time series have also reported a muted or even negative response of output; see Mountford and Uhlig (2009) or the results in Ramey (2011) and Perotti (2004) for a more recent 
Government spending

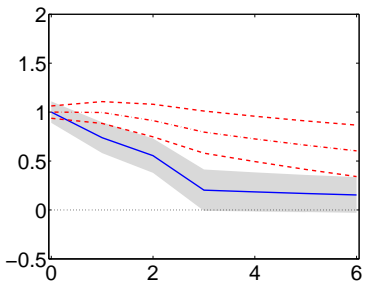

Net exports

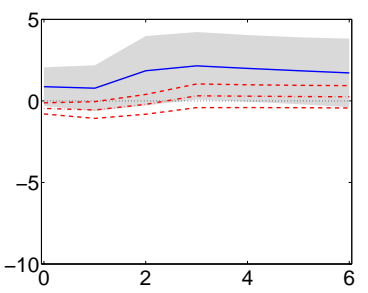

Output

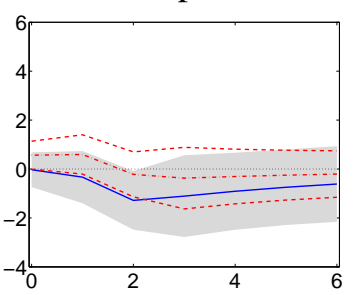

Real exchange rate

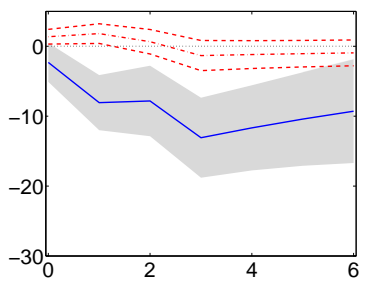

Consumption

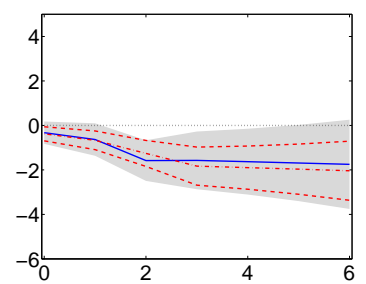

Inflation

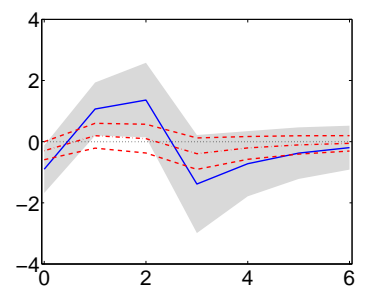

Investment

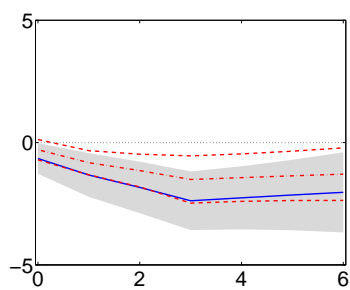

Interest rate

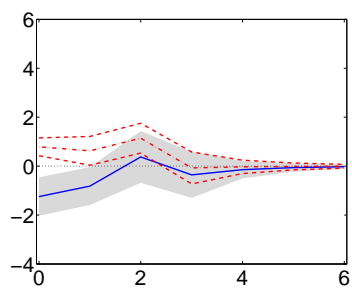

Figure 2: Impulse responses to government spending shock: baseline scenario vs peg. Notes: quantities measured in output units; solid line: point estimate for baseline scenario (shaded area: \pm one standard error); dashed dotted line (dashed lines: \pm one standard error): deviation from baseline under exchange rate peg.

sample period. Ilzetzki et al. (2011) also find no significant output effect of government spending under flexible exchange rates.

Exchange rate peg. According to conventional wisdom, fiscal policy transmission varies systematically across exchange rate regimes. Together with results for the baseline scenario, Figure 2 also displays the estimated impulse responses and confidence intervals for the case of a currency peg (assuming sound public finances and no financial crisis); these are denoted by the dashed-dotted and dashed lines, respectively.

From Figure 2 it is apparent that the output multiplier is positive and larger than in the economy with a flexible exchange rate, consistent with the textbook Mundell-Fleming model. In this dimension, our findings match those by Ilzetzki et al. (2011), who also report that the output effects of government spending shocks are significant and sizeable under fixed exchange rates. Further confirming conventional wisdom, net exports are seen to decrease, while the real exchange rate appreciates. ${ }^{33}$

However, there are also some striking differences across currency regimes which do not square well with the textbook Mundell-Fleming model. First, note that the impact responses of consumption and investment are not appreciably different under a peg relative to the case of a more flexible exchange rate. Second, and more important, while the response of inflation exhibits the same pattern across both regimes (with an initial drop followed by a rise), monetary policy appears to be much less

\footnotetext{
${ }^{33}$ Note that we classify as an exchange rate peg all currency regimes up to and including category 8 in Ilzetzki et al. (2009), that is, a "de facto crawling band that is narrower than or equal to +/-2 percent;" even a nominal peg, therefore, allows for some limited exchange rate flexibility.
} 
accommodative under a fixed exchange rate: the short rate rises on impact and remains positive for some extended period. Correspondingly, we find that the real exchange rate appreciates under a peg. It is worth stressing in this regard that the typical textbook notion of monetary policy being more accommodative under a peg is not a general prediction of standard open economy models, whether classic (Dornbusch 1980) or more modern (Corsetti et al. 2011a). Moreover, standard analysis often proceeds under the implicit assumption that the current peg is perfectly credible — an assumption that is unlikely to be satisfied in practice. With imperfect credibility (as suggested by the historical record contained in our sample), a government spending expansion may generate tensions in the currency market, prompting the central bank to defend the currency with an increase in the interest rate.

The monetary response to the identified government spending shocks also marks a key difference between our empirical results and those of Ilzetzki et al. (2011). The latter study, using a different methodology and a different sample, finds the response of the policy rate to be less accommodative under a flexible exchange rate than under a peg. Consistent with that finding, Ilzetzki et al. (2011) report that the real exchange rate tends to strengthen under a float, notably compared to the response under a peg. The pattern we detect in our sample is the opposite. Given the importance of fiscal and monetary interactions these differences clearly suggest a case for further analysis.

Nonetheless, our results regarding the real exchange rate shed light on the seemingly contradictory conclusions of earlier empirical studies that, like ours, focus on OECD countries. Some of these studies suggest a real depreciation, some a real appreciation, in response to positive government spending shocks. Much of this divergence in the literature could be explained in light of our result that the sign of the real exchange rate response appears to depend on the exchange rate regime. ${ }^{34}$ Different exchange rate regimes could also account for the mixed evidence across VAR studies as regards the impact response of net exports, pointing to interesting directions for future research into the interaction of fiscal and monetary policy. In this context, we note that our findings for the behavior of external variables under a peg — real appreciation and a trade deficit—are quite robust to alternative specifications of our model, as discussed below.

Weak public finances. We now consider a second dimension which may be critical for how government spending affects the economy, i.e., the health of public finances. Similar to Perotti (1999), we define countries as having weak public finances when beginning-of-period gross government debt exceeds 100 percent of GDP and/or lagged net government borrowing exceeds 6 percent of GDP. The

\footnotetext{
${ }^{34}$ In addition to Beetsma et al. (2008) and Bénétrix and Lane (2009), a number of studies have documented real appreciation in countries/regions with a fixed exchange rate. In their analysis of U.S. states and EMU member countries, Canova and Pappa (2007) find that government spending shocks raise the price level relative to the price level in the rest of the union. Relying on a static regression model estimated on data for OECD countries, Lane and Perotti (2003) find that an increase in the government wage bill appreciates the nominal exchange rate. Ricci, Milesi-Ferretti, and Lee (2008) also document a positive association between government consumption and the real exchange rate for a panel of 48 countries.
} 


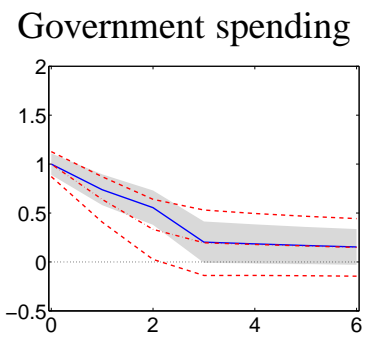

Net exports

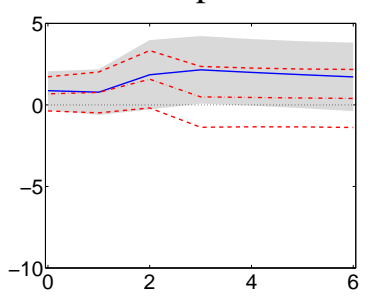

Output

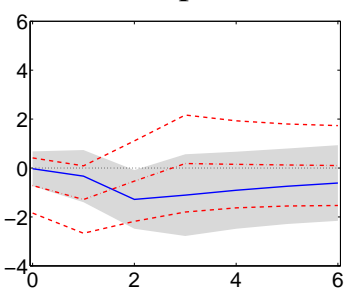

Real exchange rate

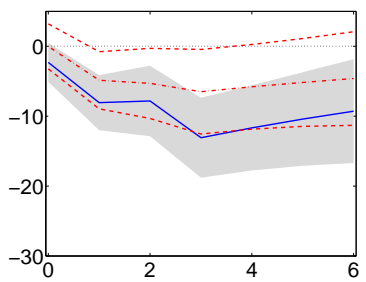

Consumption

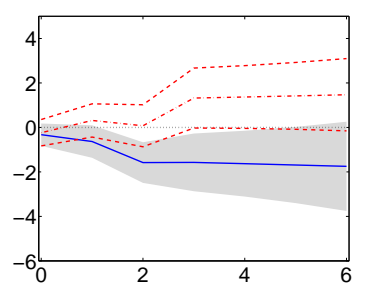

Inflation

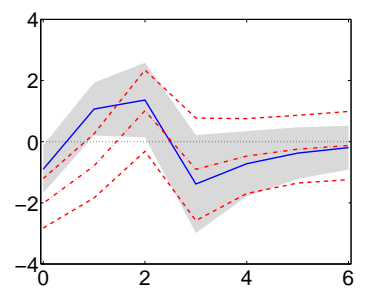

Investment

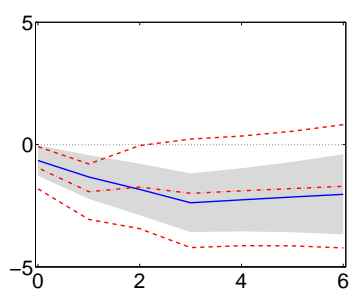

Interest rate

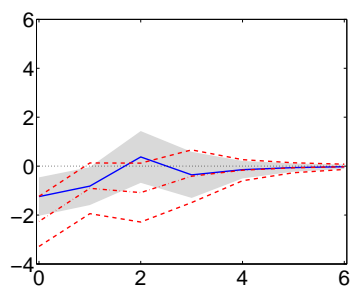

Figure 3: Impulse responses to government spending shock: baseline scenario vs situation of weak public finances. Notes: see Figure 2.

dashed lines in Figure 3 show the effects of government spending shocks for such an economy, while the solid lines display the responses under the baseline scenario of sound public finances.

We find that, in the case of weak public finances, the impact response of output and investment is lower relative to the baseline scenario. Contrasting with our theoretical priors, however, there is no difference in the impact response of consumption. Moreover, the response of consumption turns positive over time. Meanwhile, inflation and the interest rate follow similar patterns as in the baseline scenario with sound public finances, but their responses are more pronounced. Both the initial decline in inflation and the subsequent peak are larger, and the monetary stance is looser throughout. Conversely, the exchange rate does not respond on impact and depreciates by less over time.

As differences relative to the baseline are nonetheless moderate, with the exception of the puzzling delayed increase of consumption, our results are likely to reflect the fact that high public debt and lagged deficits are not sufficiently precise indicators for the kind of fiscal stress that we would expect to affect the fiscal transmission mechanism. Japan's long experience of living with very high and rising public debt and yet very low financing costs testifies to the empirical challenge facing research in this area. ${ }^{35}$

Financial crisis. The last set of results pertains to the distinction between normal times and times of financial crisis. The possibility that a financial crisis affects fiscal policymaking is already captured in our first-stage specification. The analysis in this section focuses on the effect of a given fiscal

\footnotetext{
${ }^{35}$ The analysis of Corsetti et al. (2012) also suggests that high debt has a decisive effect on fiscal transmission only if monetary policy is constrained.
} 
Government spending

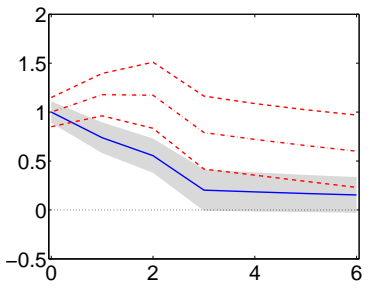

Net exports

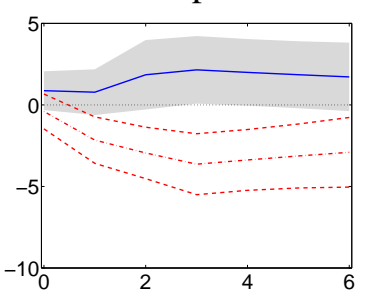

Output

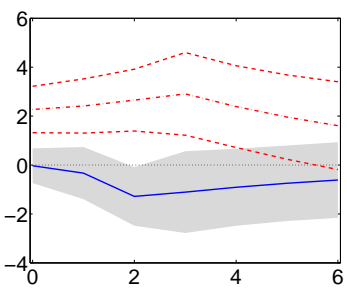

Real exchange rate

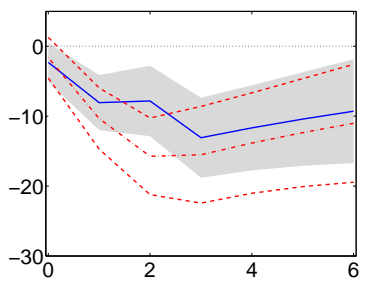

Consumption

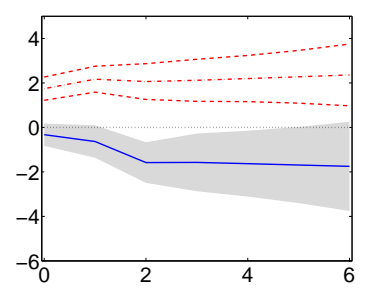

Inflation

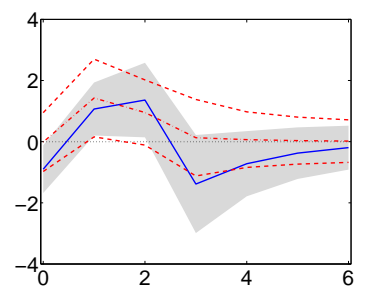

Investment

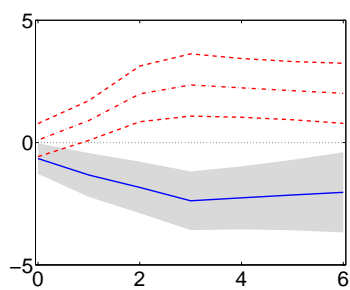

Interest rate

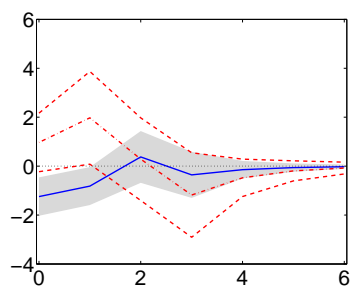

Figure 4: Impulse responses to government spending shock: baseline scenario vs financial crisis. Notes: see Figure 2.

expansion (above and beyond what is explained by the systematic response of spending to cyclical conditions) during times of financial crisis.

Our results, shown in Figure 4, suggest that the response of consumption and output to a fiscal expansion is positive and large once we condition on the occurrence of a financial crisis: consumption and output rise about twice as much as the initial increase in government spending. Correspondingly, the trade balance deteriorates significantly and persistently. The response of investment is initially muted, but appears to strengthen over time. ${ }^{36}$

During a financial crisis, a spending expansion appears to be associated with more inflation and currency depreciation than in the baseline scenario. Most importantly, it prompts a sharp, albeit temporary, rise in interest rates. In light of the strong depreciation response of the exchange rate, these patterns may point to a policy model whereby the central bank, even at times of financial crisis, specifically targets currency stability.

On the one hand, our findings support the argument that higher fiscal outlays are particularly effective as a stabilization tool in a financial crisis, perhaps because agents are liquidity-constrained. In fact, the recent policy debate in the United States has featured repeated claims that fiscal multipliers could be as large as two under current conditions. Our estimates are consistent with a multiplier of this magnitude, even though our results for "normal times" do not suggest large fiscal multipliers at all.

On the other hand, it is worth stressing that not all historical financial crises in our sample have

\footnotetext{
${ }^{36}$ We are not aware of empirical studies attempting to quantify the impact of financial crises on fiscal policy transmission. On a related theme, however, Tagkalakis (2008) finds that recessions, more broadly defined, tend to raise the government spending multiplier on consumption. Ilzetzki et al. (2011) and Auerbach and Gorodnichenko (2010, 2011) also find stronger output multipliers during recessions.
} 
induced policymakers to increase exhaustive government spending. As shown above, the crisis dummy in our first-step regression takes on a negative sign for several countries, probably reflecting concerns about financing or fiscal sustainability. Indeed, it seems plausible that fiscal sustainability is a crucial precondition for obtaining high positive multipliers at times of financial crisis (as discussed in Corsetti et al. 2012). In that sense, our findings also contain a warning that a financial crisis can be even more damaging if it forces the government to retrench spending in the midst of the downturn. This clearly underscores the case for preserving and strengthening fiscal buffers in good times.

A final caveat is in order: the number of observations of financial crises is necessarily limited in our sample, and although we follow the classification of Reinhart and Rogoff (2008), not all of these financial crisis episodes are identical or even similar in their nature and depth. Nevertheless, as we show in the following, our main results appear quite robust to changes in the definitions of our dummies, including a narrower definition of financial crisis, and the specification of our empirical model.

\subsection{Sensitivity analysis}

We explore the robustness of our results with respect to alternative definitions of the dummy variables and model specifications. Results are shown in Figures 5 through 11 in the appendix, where each column displays results for one of three possible departures from the baseline scenario, i.e. financial crisis, weak public finances, and an exchange rate peg. Starting with Figure 5, we display results obtained under a narrower definition of financial crisis, including only the so-called "big five" banking crises (Finland 1991-94, Japan 1992-97, Norway 1988-93, Spain 1978-85, and Sweden 1991-94) plus the global financial crisis starting in 2007. Clearly, a narrower definition of financial crisis has the advantage of selecting crises with a comparably large magnitude, albeit at the price of reducing the number of observations considerably.

In each column we also report results for the baseline scenario (no peg, low debt, no crisis). Generally, our findings are not much altered relative to those obtained under the wider definition of financial crisis. The impulse responses conditional on a financial crisis are shown by the panels in the left column. While the overall results of Figure 4 are confirmed, there are three notable differences. First, government spending itself appears to be less persistent. Second, while the impact response for output and consumption remains close to 2, overall activity reverts to the trend more quickly. Third, the responses of inflation and the real exchange rate are stronger, matched by a sharper rise in the short-term interest rate.

A narrower definition of the crisis dummy does not affect multipliers conditional on high debt, shown in the second column of Figure $5 .{ }^{37}$ By contrast, it appears to strengthen our results concerning the

\footnotetext{
${ }^{37}$ Note, however, that the puzzling result of a delayed rise in consumption disappears in this specification.
} 
impact of fiscal shocks under a peg. As apparent from the right column, the difference in the impact responses of output and investment across currency regimes is larger than in Figure 2.

Figure 6 reports impulse responses for the case of a stricter definition of weak public finances, with the relevant thresholds for debt and the deficit raised to 120 percent and 7 percent of GDP, respectively. In this case, the results conditional on financial crisis and weak public finances are not substantially affected. The most apparent change concerns the currency regime. As shown by the right column of Figure 6, our main result regarding output and investment is reversed: the point estimates of their impact responses are now lower under a peg, relative to a regime of flexible exchange rates. In contrast, the responses of external variables, i.e., the real exchange rate and the trade balance, are similar, if not stronger, than in Figure 2. The real exchange rate appreciates on impact, and the trade deficit worsens.

Figure 7 displays results for the model specified in differences, rather than levels. To allow a comparison with the results obtained above, we consider the cumulative effect of a government spending shock. Overall, the results from the level specification turn out to be quite robust with respect to this alternative specification. Unexpected spending increases are again found to be considerably more effective during financial crises than in normal times. The output and consumption multipliers remain around 2, investment rises over time, net exports deteriorate, and the real exchange rate depreciates. Similarly, Figure 7 confirms our previous conclusions regarding the effects of fiscal policy conditional on weak public finances and an exchange rate peg. If anything, results under a peg, especially those concerning the output multiplier, are more clearly in line with the received wisdom. Figure 8 reports impulse responses for a specification where we include the contemporaneous rather than the lagged value of the crisis dummy in the first step. This amounts to assuming that, during crises, the government can considerably shorten decision and implementation lags regarding its planned consumption expenditure, allowing for a systematic within-year response of government spending to a financial crisis. While this hypothesis is hardly supported by the data, our exercise can shed light on the extent to which our main findings may be driven by a shortcoming in our identification strategy specific to crisis episodes. As apparent from the figure, results are quite similar to those obtained under the standard specification, reported in Figures 2 through $4 .{ }^{38}$

In Figure 9, in turn, we display the results obtained if we exclude the lagged values of the OECD's Composite Leading Indicator from the first step. The inclusion of this variable in our model is meant to account for any advance information about cyclical developments in the economy which the government may use in preparing its next budget. Omitting it would mean that some changes

\footnotetext{
${ }^{38} \mathrm{~A}$ related concern is that our crisis dummy may be too crude a measure of financial dislocations. As some crises are deeper than others, and some crisis years in a given crisis episode are worse than others, including the crisis dummy may not prevent our estimated shocks from containing some systematic fiscal response to the crisis. To assess this issue, we estimated the model excluding all those countries for which we estimate a negative crisis coefficient in the first step. Results from this exercise (not shown due to space constraints) do not bear out this concern.
} 
in spending decided in anticipation of cyclical movements could be mistaken for policy innovations. However, there is also a potential error working in the opposite direction: suppose that spending has no effect on output (the multiplier is zero), but policymakers believe it to be an effective stabilization instrument. In this case, including the CLI in the first step may induce a spurious correlation between fiscal policy and output, even if there is none. ${ }^{39}$ The sign of such a bias in the multiplier would depend on the cyclical properties of spending, for which the evidence is mixed. In any case, Figure 9 suggests that our main results are not sensitive to omitting the CLI from the first step, with the exception of the response of GDP and its components under a peg. As was the case for the more restrictive definition of high debt (Figure 5), fiscal multipliers appear to be smaller under a peg, while the response of the trade balance and the exchange rate remain similar to the evidence in Figure 2.

Next, we consider results for alternative time dimensions of our sample. First, we limit the sample to end in 2006 in order to exclude observations pertaining to the global financial crisis (Figure 10). Indeed, the response time of fiscal policy appears to have been unusually short during this latest episode, potentially jeopardizing our identification strategy. In a separate (unreported) robustness check, we extend our sample to the early 1970s, thus including a number of observations from the late stages of the Bretton Woods period. Neither of these experiments generates appreciable differences relative to our results for the baseline sample. Thus, the observations for the first two years of the global financial crisis do not seem to be influential in driving the different multipliers we estimate. By the same token, the transmission of fiscal policy does not appear to be specific to the international monetary system that emerged after the demise of Bretton Woods.

We conclude our sensitivity analysis with one additional variation of the baseline setup. Results shown in Figure 11 are based on estimates where the United States are excluded from the sample. This addresses concerns that the United States are a possible outlier with respect to the effects of fiscal policy. In the event, we find that results are broadly unchanged relative to our baseline setup.

\footnotetext{
${ }^{39}$ We thank Mike Woodford for raising this issue.
} 


\section{Conclusion}

Economic theory suggests that the transmission of fiscal policies may vary across economic environments - there is no single multiplier describing the effectiveness of fiscal stimulus. However, empirical evidence on the determinants of fiscal transmission has remained patchy. In this paper we take a step toward a systematic empirical analysis of how different economic conditions affect the transmission of government spending shocks. Specifically, we propose a two-stage procedure to estimate impulse response functions for economies that differ in terms of their exchange rate regime, the health of their public finances, and the state of their financial systems. While our findings confirm standard estimates of average fiscal multipliers, they also suggest that these averages mask substantial differences across economic environments.

Two main results stand out. First, we find that the real exchange rate response to a spending shock varies systematically with the exchange rate regime. This underscores the importance of interactions between fiscal and monetary policy - an interesting avenue for future research, especially in an open economy context. Our finding also sheds new light on the debate about fiscal transmission via international prices. Specifically, several recent studies have documented exchange rate depreciation after a spending increase, contrary to the prediction of standard theoretical models. These studies tend to focus on samples including Australia, the United States, and the United Kingdom, i.e., countries with floating exchange rate regimes, whereas other studies finding real appreciation typically consider samples dominated by euro area countries. Our analysis indicates that these differences may be systematically related to distinct exchange rate regimes.

A second finding with direct policy implications concerns the marked increase in fiscal multipliers during times of financial crisis. On the one hand, this may be taken as evidence in support of fiscal stimulus during times of acute financial stress. On the other hand, our empirical results also show that many countries have historically cut back government spending during financial crises, presumably out of concern over debt sustainability. In this sense, a large conditional multiplier provides a stark warning about the costs of financial turmoil and an argument in favor of building up fiscal buffers in normal times so as to avoid fiscal retrenchment when it is most painful. 


\section{References}

A. Acconcia, G. Corsetti, and S. Simonelli. Mafia and public spending: Evidence of the fiscal multiplier from a quasi-experiment. mimeo, 2011.

A. Afonso and J. Jalles. Assessing fiscal episodes. Technical university of Lisbon Working Paper 15/2011, 2011.

A. Auerbach and Y. Gorodnichenko. Measuring the output responses to fiscal policy. American Economic Journal: Economic Policy, forthcoming, 2010.

A. Auerbach and Y. Gorodnichenko. Fiscal multipliers in recession and expansion. NBER Working paper 17447, 2011.

D. Backus, P. Kehoe, and F. Kydland. Dynamics of the trade balance and the terms of trade: the J-curve? American Economic Review, 84(1):84-103, March 1994.

E. Baldacci, S. Gupta, and C. Mulas-Granados. How effective is fiscal policy response in systemic banking crises? IMF Working Paper WP/09/160, 2001.

R. Barro and C. J. Redlick. Macroeconomic effects from government purchases and taxes. Quarterly Journal of Economics, 126:51-102, 2011.

M. Baxter and R. G. King. Fiscal policy in general equilibrium. American Economic Review, 83(3): 315-334, June 1993.

R. Beetsma, M. Giuliodori, and F. Klaasen. Trade spill-overs of fiscal policy in the European Union: a panel analysis. Economic Policy, 48:640-687, 2006.

R. Beetsma, M. Giuliodori, and F. Klaasen. The effects of public spending shocks on trade balances in the European Union. Journal of the European Economic Association, 6(2-3):414-423, 2008.

R. Beetsma, M. Giuliodori, and F. Klaassen. Temporal aggregation and svar identification, with an application to fiscal policy. Economics Letters, 105:253-255, 2009.

A. S. Bénétrix and P. R. Lane. Fiscal shocks and the real exchange rate, 2009. IIIS Discussion Paper 286.

G. Bertola and A. Drazen. Trigger points and budget cuts: Explaining the effects of fiscal austerity. American Economic Review, 83(1):11-26, 1993.

F. O. Bilbiie, A. Meier, and G. J. Müller. What accounts for the changes in U.S. fiscal policy transmission? Journal of Money, Credit, and Banking, 40(7):1439-1469, 2008. 
O. J. Blanchard and R. Perotti. An empirical characterization of the dynamic effects of changes in government spending and taxes on output. Quarterly Journal of Economics, 117(4):1329-1368, November 2002.

B. Born and G. J. Müller. Government spending in quarterly and annual time series. Journal of Money, Credit and Banking, 44(2-3):507-517, 2012.

C. Burnside, M. Eichenbaum, and J. D. Fisher. Fiscal shocks and their consequences. Journal of Economic Theory, 115:89117, 2004.

F. Canova and E. Pappa. Price differentials in monetary unions: The role of fiscal shocks. Economic Journal, 117:713-737, March 2007.

M. B. Canzoneri, R. E. Cumby, and B. Diba. New view on the transatlantic transmission of fiscal policy and macroeconomic policy coordination. In M. Buti, editor, Monetary and Fiscal Policies in EMU, pages 283-311. Cambridge University Press, 2003.

L. Christiano, M. Eichenbaum, and C. Evans. The effects of monetary policy shocks: Evidence from the flow of funds. Review of Economics and Statistics, 78(1):16-34, 1996.

L. Christiano, M. Eichenbaum, and S. Rebelo. When is the government spending multiplier large? Journal of Political Economy, 119(1):78-121, 2011.

J. Cimadomo. Real-time data and fiscal policy analysis: a survey of the literature. Working Papers 11-25, Federal Reserve Bank of Philadelphia, 2011.

J. F. Cogan, T. Cwik, J. B. Taylor, and V. Wieland. New Keynesian versus old Keynesian government spending multipliers. Journal of Economic Dynamics and Control, 34, 2010.

G. Corsetti and G. J. Müller. Twin deficits: Squaring theory, evidence and common sense. Economic Policy, 48:598-638, 2006.

G. Corsetti, K. Kuester, and G. J. Müller. Pegs, floats and the transmission of fiscal policy. CEPR Discussion paper 8180, 2011a.

G. Corsetti, A. Meier, and G. J. Müller. Fiscal stimulus with spending reversals. Review of Economics and Statistics, forthcoming, 2011b.

G. Corsetti, K. Kuester, A. Meier, and G. J. Müller. Sovereign risk, fiscal policy, and macroeconomic stability. IMF Working paper 12/33, 2012.

R. Dornbusch. Exchange rate economics: Where do we stand. Brookings Papers on Economic Activity, 1:143-185, 1980. 
W. Edelberg, M. Eichenbaum, and J. D. M. Fischer. Understanding the effects of a shock to government purchases. Review of Economic Dynamics, 2:166-206, 1999.

G. B. Eggertsson and M. Woodford. The zero interest-rate bound and optimal monetary policy. Brookings Papers on Economic Activity, 1:139-211, 2003.

Z. Enders, G. J. Müller, and A. Scholl. How do fiscal and technology shocks affect real exchange rates? New evidence for the U.S. Journal of International Economics, 83:53-69, 2011.

C. Erceg and J. Lindé. Is there a fiscal free lunch in a liquidity trap? CEPR Discussion Paper No. 7624, 2010.

C. Erceg, C. Gust, and D. López-Salido. The transmission of domestic shocks in open economies. In J. Gali and M. Gerlter, editors, International Dimensions of Monetary Policy. University of Chicago Press, 2010.

J. Fernández-Villaverde. Fiscal policy in a model with financial frictions. American Economic Review: Papers \& Proceedings, 100:35-40, May 2010.

J. Galí and R. Perotti. Fiscal policy and monetary integration in Europe. Economic Policy, 37: 534-572, 2003.

J. Galí, J. D. López-Salido, and J. Vallés. Understanding the effects of government spending on consumption. Journal of the European Economic Association, pages 227-270, 2007.

F. Giavazzi and M. Pagano. Can severe fiscal contractions be expansionary? Tales of two small European countries. NBER Macroeconomics Annual, 5:75-111, 1990.

F. Giavazzi, T. Jappelli, and M. Pagano. Searching for non-linear effects of fiscal policy: Evidence from industrial and developing countries. European Economic Review, 44:1259-1289, 2000.

R. E. Hall. By How Much Does GDP Rise if the Governmernt Buys More Output? Brookings Papers on Economic Activity, (2):183-231, 2009.

J. D. Hamilton. Time Series Analysis. Princeton University Press, 1994.

E. O. Ilzetzki, C. Reinhart, and K. Rogoff. Exchange rate arrangements entering the 21st century: Which anchor will hold?, 2009. Mimeo.

E. O. Ilzetzki, E. Mendoza, and C. Vegh. How big (small?) are fiscal multipliers?, 2011. mimeo.

International Monetary Fund. From recession to recovery: How soon and how strong? World Economic Outlook, April:103-138, 2009. 
S. Kim and N. Roubini. Twin deficit or twin divergence? Fiscal policy, current account, and real exchange rate in the U.S. Journal of International Economics, 74(2):362-383, 2008.

R. Kollmann. Government purchases and the real exchange rate. Open Economies Review, 21:49-64, 2010.

P. R. Lane and R. Perotti. The importance of composition of fiscal policy: Evidence from different exchange rate regimes. Journal of Public Economics, 87:2253-2279, 2003.

L. Linnemann and A. Schabert. Fiscal policy and the new neoclassical synthesis. Journal of Money, Credit and Banking, 35(6):911-929, 2003.

T. Monacelli and R. Perotti. Fiscal policy, the real exchange rate and traded goods. Economic Journal, 120:437-461, 2010.

A. Mountford and H. Uhlig. What are the effects of fiscal policy shocks? Journal of Applied Econometrics, 24(6):960-992, 2009.

W. Newey and D. McFadden. Large sample estimation and hypothesis testing. In R. Engle and D. McFadden, editors, Handbook of Econometrics, volume 4, chapter 36, pages 2111-2245. Elsevier, 1994.

M. Obstfeld and K. Rogoff. Exchange rate dynamics redux. Journal of Political Economy, 103: 624-660, 1995.

R. Perotti. Fiscal policy in good times and bad. Quarterly Journal of Economics, 114(4):1399-1436, November 1999.

R. Perotti. Estimating the effects of fiscal policy in OECD countries. mimeo, 2004.

R. Perotti. In search of the transmission mechanism of fiscal policy. NBER Working paper 13143, 2007.

V. A. Ramey. Identifying government spending shocks: It's all in the timing. Quarterly Journal of Economics, 126(1):1-50, 2011.

V. A. Ramey and M. D. Shapiro. Costly capital reallocation and the effects of government spending. Carnegie Rochester Conference on Public Policy, 48:154-194, 1998.

M. O. Ravn, S. Schmitt-Grohé, and M. Uribe. Consumption, government spending, and the real exchange rate. Journal of Monetary Economics, 59:215-234, 2012.

C. Reinhart. This time is different chartbook: Country histories on debt, default, and financial crisis. NBER Working Paper 15815, 2010. 
C. Reinhart and K. Rogoff. Banking crises: An equal opportunity menace, 2008. NBER Working Paper 14587.

L. A. Ricci, G. M. Milesi-Ferretti, and J. Lee. Real exchange rates and fundamentals: A cross-country perspective. IMF Working Paper 08/13, 2008.

J. Rotemberg and M. Woodford. Oligopolistic pricing and the effects of aggregate demand on economic activity. Journal of Political Economy, 100(6):1153-1207, 1992.

C. Sims. Comment on Glenn Rudebusch's “Do measures of monetary policy in a var make sense?". International Economic Review, 39:933-941, 1998.

A. Sutherland. Fiscal crisis and aggregate demand: Can high public debt reverse the effects of fiscal policy? Journal of Public Economics, 65:147-162, 1997.

A. Tagkalakis. The effects of fiscal policy on consumption in recessions and expansions. Journal of Public Economics, 92:14861508, 2008.

M. Woodford. Simple analytics of the government expenditure multiplier. American Economic Journal: Macroeconomics, 3:1-35, 2011. 


\section{Tables and additional figures}

Table 1. Composition of Initial and Final Samples

\begin{tabular}{ccc}
\hline Country & \multicolumn{2}{c}{ Time Period Included } \\
\hline Australia & Initial Sample 1/ & Final Sample 2/ \\
Austria & $1989-2008$ & $1992-2008$ \\
Belgium & $1975-2008$ & $1978-2008$ \\
Canada & $1975-2008$ & $1978-2008$ \\
Denmark & $1975-2002,2004-08$ & $1978-2001,2007-08$ \\
Finland & $1975-2008$ & $1978-2008$ \\
France & $1986-92,1995-2008$ & $1989-91,1998-2008$ \\
Ireland & $1979-2008$ & $1982-2008$ \\
Italy & $1980-2008$ & $1983-2008$ \\
Japan & $1975,1977-1992,1995-2008$ & $1980-1991,1998-2008$ \\
Netherlands & $1975-2008$ & $1978-2008$ \\
Norway & $1975-2008$ & $1978-2008$ \\
Portugal & $1975-2008$ & $1978-2008$ \\
Spain & $1987-2008$ & $1990-2008$ \\
Sweden & $1981-2008$ & $1984-2008$ \\
UK & $1975-2008$ & $1978-2008$ \\
USA & $1975-90,1992,1994-2008$ & $1978-1989,1997-2008$ \\
Total no. of observations: & $1975-78,1980-2008$ & 444 \\
\hline
\end{tabular}

1/ Initial sample comprises the same set of OECD countries considered in Perotti (1999), with maximum time period 1975-2008, depending on data availability. Missing observations for individual years within a given time series accounted for by within-year changes in the exchange rate regime, which preclude an unequivocal coding.

2/ Final sample determined by availability of all regressors included in the most comprehensive specification for second-step regression. 
Table 2. Data Sources and Definitions

Variable Definition Data Sources

Government spending

GDP

CLI

Public debt

Financial crisis dumm

Bad fiscal times dummy

Peg dummy

Private consumption

Private investmen

Trade balance

REER

Interest rate

Inflation
Takes on value of 1 during financial crises, and 0 otherwise

Takes on value of 1 when lagged public debt exceeds 100 percent of GDP or lagged government net borrowing exceeds 6 percent of GDP, and 0 otherwise

Takes on value of 1 when exchange rate regime defined as peg, and 0 otherwise

Log per capita real private consumption

Log per capita real fixed investment

Ratio of net exports to GDP

Log of real per capita government consumption

Log of per capita GDP

General government gross debt (in percent of

CPI-based real effective exchange rate (in percent)

Nominal short-term interest rate

Annual change in Consumer Price Index (all items) average for the year
OECD Economic Outlook Database: volume of final government consumption expenditure (CGV) OECD Analytic Database: population size (POP)

OECD Economic Outlook Database: value of gross domestic product (GDP), GDP deflator (PGDP); OECD Analytic Database: population size (POP).

OECD Main Economic Indicators database: CLI amplitude-adjusted; normalized by subracting 100, and dividing by 100 .

Primary source: IMF World Economic Outlook: General government gross debt (GGD), nominal GDP (NGDP); where unavailable: OECD Analytic Database: General government gross financial liabilities as a percentage of GDP (GGFLQ); for Sweden: Statistics Sweden: Central government gross debt in percent of GDP

Reinhart and Rogoff (2008, pp. 65 ff.) and Reinhart and Rogoff (2010): the relevant crisis episodes, broadly defined, are (severe financial crises in bold): Australia 1989-92; Austria 2008; Belgium 2008; Canada 1983-85; Denmark 1987-92 and 2008; Finland 1991-94; France 1994-95; Germany 2007-08; Ireland 2007-08; Italy 1990-94 and 2008; Japan 1992-97; Netherlands 2008; Norway 1988-93; Spain 1978-85 and 2008; Sweden 1991-94; United Kingdom 1974-76, 1984, and 2007-08; and United States 1984-91 and 2007-08.

OECD Analytic Database: Government net lending as a percentage of GDP (NLGQ); see also entry for public debt above.

Ilzetzki, Reinhart, and Rogoff (2008): categories 1-8 of the authors' fine classification scheme are defined as "peg"; category 14 ("freely falling") coded as "not available"; within-year changes in regime category also lead to coding as "not available"; time series updated for 2008 (identical classification as for 2007) by the authors.

OECD Economic Outlook Database: volume of final private consumption expenditure (CPV); OECD Analytic Database: population size (POP)

OECD Economic Outlook Database: volume of private total fixed capital formation (IPV); OECD Analytic Database: population size (POP)

IMF World Economic Outlook: exports of goods and services at current prices (NX), imports of goods and services at current prices (NM), nominal GDP (NGDP)

OECD Main Economic Indicators Database (CCRETT01.IXOB).

IMF International Financial Statistics: money market rate.

OECD Main Economic Indicators Database (CPALTT01.GY). 
Table 3. Results of First-Step Regression 1/

\begin{tabular}{|c|c|c|c|c|c|c|c|c|c|c|c|c|c|c|c|c|c|c|c|}
\hline \multirow{3}{*}{$\begin{array}{l}\begin{array}{l}\text { Dependent variable: Log } \\
\text { of per capita government } \\
\text { consumption }\end{array} \\
\\
\text { Country } \\
\text { Australia }\end{array}$} & \multicolumn{16}{|c|}{ Regressor } & \multirow{3}{*}{$\begin{array}{c}\begin{array}{c}\text { F-test of joint } \\
\text { significance } \\
(p-v a l u e)\end{array} \\
0.00\end{array}$} & \multirow{3}{*}{$\begin{array}{c}\text { R squared } \\
1.00\end{array}$} & \multirow{3}{*}{$\begin{array}{c}\begin{array}{c}\text { Arellano-Bond } \\
\text { test of } \\
\text { autocorrelatior } \\
\text { (p-value) }\end{array} \\
0.28\end{array}$} \\
\hline & \multicolumn{2}{|c|}{$\begin{array}{c}\text { Government } \\
\text { spending } \\
(-1) \\
\end{array}$} & \multicolumn{2}{|c|}{$\begin{array}{c}\text { Government } \\
\text { spending } \\
(-2) \\
\end{array}$} & \multicolumn{2}{|c|}{$\operatorname{GDP}(-1)$} & \multicolumn{2}{|c|}{$\operatorname{GDP}(-2)$} & \multicolumn{2}{|c|}{ CLI (-1) } & $\begin{array}{c}\text { Bad fiscal } \\
\text { times } \\
\text { dummy } \\
\end{array}$ & \multicolumn{2}{|c|}{$\begin{array}{l}\text { Lagged fin. } \\
\text { crisis } \\
\text { dummy }\end{array}$} & $\begin{array}{c}\text { Lagged peg } \\
\text { dummy }\end{array}$ & \multicolumn{2}{|c|}{$\begin{array}{c}\text { Beginning-of- } \\
\text { period govt. } \\
\text { debt } \\
\end{array}$} & & & \\
\hline & $\begin{array}{l}-0.210 \\
(0.300)\end{array}$ & & $\begin{array}{l}-0.315 \\
(0.218)\end{array}$ & & $\begin{array}{l}0.159 \\
(0.153)\end{array}$ & & $\begin{array}{l}0.240 \\
(0.230)\end{array}$ & & $\begin{array}{l}0.055 \\
(0.094)\end{array}$ & & . & $\begin{array}{l}-0.000 \\
(0.009)\end{array}$ & & . & $\begin{array}{l}-0.139 \\
(0.071)\end{array}$ & * & & & \\
\hline Austria & $\begin{array}{l}1.344 \\
(0.176)\end{array}$ & $* * \star$ & $\begin{array}{l}-0.507 \\
(0.169)\end{array}$ & $* * *$ & $\begin{array}{l}-0.320 \\
(0.148)\end{array}$ & ** & $\begin{array}{l}0.245 \\
(0.144)\end{array}$ & & $\begin{array}{l}0.020 \\
(0.069)\end{array}$ & & . & . & & . & $\begin{array}{l}0.009 \\
(0.033)\end{array}$ & & 0.00 & 1.00 & 0.56 \\
\hline Belgium & $\begin{array}{l}0.554 \\
(0.197)\end{array}$ & $* \star \star$ & $\begin{array}{l}0.194 \\
(0.175)\end{array}$ & & $\begin{array}{l}0.056 \\
(0.154)\end{array}$ & & $\begin{array}{l}-0.103 \\
(0.166)\end{array}$ & & $\begin{array}{l}-0.054 \\
(0.097)\end{array}$ & & $\begin{array}{l}0.014 \\
(0.009)\end{array}$ & . & & & $\begin{array}{l}-0.041 \\
(0.014)\end{array}$ & $* * *$ & 0.00 & 0.99 & 0.11 \\
\hline Canada & $\begin{array}{l}0.916 \\
(0.192)\end{array}$ & $* * *$ & $\begin{array}{l}-0.004 \\
(0.162)\end{array}$ & & $\begin{array}{l}0.190 \\
(0.171)\end{array}$ & & $\begin{array}{l}-0.069 \\
(0.195)\end{array}$ & & $\begin{array}{l}-0.141 \\
(0.077)\end{array}$ & * & $\begin{array}{l}-0.016 \\
(0.010)\end{array}$ & $\begin{array}{l}0.015 \\
(0.011)\end{array}$ & & $\begin{array}{l}0.001 \\
(0.016)\end{array}$ & $\begin{array}{l}-0.020 \\
(0.043)\end{array}$ & & 0.00 & 0.98 & 0.38 \\
\hline Denmark & $\begin{array}{l}1.007 \\
(0.199)\end{array}$ & $* * *$ & $\begin{array}{l}-0.084 \\
(0.205)\end{array}$ & & $\begin{array}{l}-0.024 \\
(0.210)\end{array}$ & & $\begin{array}{l}-0.111 \\
(0.216)\end{array}$ & & $\begin{array}{l}0.076 \\
(0.088)\end{array}$ & & $\begin{array}{l}-0.015 \\
(0.017)\end{array}$ & $\begin{array}{l}-0.010 \\
(0.009)\end{array}$ & & . & $\begin{array}{l}-0.005 \\
(0.017)\end{array}$ & & 0.00 & 0.99 & 0.97 \\
\hline Finland & $\begin{array}{l}1.060 \\
(0.363)\end{array}$ & $* *$ & $\begin{array}{l}-0.432 \\
(0.371)\end{array}$ & & $\begin{array}{l}0.431 \\
(0.220)\end{array}$ & * & $\begin{array}{l}-0.077 \\
(0.249)\end{array}$ & & $\begin{array}{l}-0.020 \\
(0.084)\end{array}$ & & $\begin{array}{l}0.012 \\
(0.011)\end{array}$ & $\begin{array}{l}-0.000 \\
(0.019)\end{array}$ & & . & $\begin{array}{l}0.082 \\
(0.115)\end{array}$ & & 0.00 & 0.99 & 0.74 \\
\hline France & $\begin{array}{l}0.610 \\
(0.200)\end{array}$ & $* \star *$ & $\begin{array}{l}0.277 \\
(0.183)\end{array}$ & & $\begin{array}{l}0.085 \\
(0.221)\end{array}$ & & $\begin{array}{l}0.092 \\
(0.267)\end{array}$ & & $\begin{array}{l}-0.089 \\
(0.142)\end{array}$ & & $\begin{array}{l}-0.008 \\
(0.011)\end{array}$ & $\begin{array}{l}-0.000 \\
(0.007)\end{array}$ & & . & $\begin{array}{l}-0.071 \\
(0.036)\end{array}$ & * & 0.00 & 1.00 & 0.43 \\
\hline Ireland & $\begin{array}{l}0.709 \\
(0.181)\end{array}$ & $* \star *$ & $\begin{array}{l}-0.075 \\
(0.171)\end{array}$ & & $\begin{array}{l}0.002 \\
(0.233)\end{array}$ & & $\begin{array}{l}-0.008 \\
(0.238)\end{array}$ & & $\begin{array}{l}0.466 \\
(0.162)\end{array}$ & ** & $\begin{array}{l}-0.011 \\
(0.028)\end{array}$ & $\begin{array}{l}-0.046 \\
(0.024)\end{array}$ & * & . & $\begin{array}{l}-0.188 \\
(0.087)\end{array}$ & ** & 0.00 & 1.00 & 0.42 \\
\hline Italy & $\begin{array}{l}1.099 \\
(0.208)\end{array}$ & $* \star *$ & $\begin{array}{l}-0.235 \\
(0.200)\end{array}$ & & $\begin{array}{l}0.299 \\
(0.225)\end{array}$ & & $\begin{array}{l}0.013 \\
(0.258)\end{array}$ & & $\begin{array}{l}-0.008 \\
(0.105)\end{array}$ & & . & $\begin{array}{l}-0.015 \\
(0.009)\end{array}$ & & $\begin{array}{l}-0.006 \\
(0.010)\end{array}$ & $\begin{array}{l}-0.070 \\
(0.046)\end{array}$ & * & 0.00 & 0.99 & 0.95 \\
\hline Japan & $\begin{array}{l}0.620 \\
(0.114)\end{array}$ & 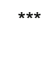 & $\begin{array}{l}0.205 \\
(0.129)\end{array}$ & & $\begin{array}{l}-0.519 \\
(0.155)\end{array}$ & ${ }^{* * *}$ & $\begin{array}{l}0.602 \\
(0.168)\end{array}$ & $* * *$ & $\begin{array}{l}0.059 \\
(0.057)\end{array}$ & & $\begin{array}{l}-0.009 \\
(0.009)\end{array}$ & $\begin{array}{l}-0.018 \\
(0.007)\end{array}$ & ** & $\begin{array}{l}-0.002 \\
(0.012)\end{array}$ & $\begin{array}{l}-0.010 \\
(0.058)\end{array}$ & & 0.00 & 1.00 & 0.34 \\
\hline Netherlands & $\begin{array}{l}0.784 \\
(0.189)\end{array}$ & $* * *$ & $\begin{array}{l}-0.210 \\
(0.221)\end{array}$ & & $\begin{array}{l}-0.154 \\
(0.286)\end{array}$ & & $\begin{array}{l}-0.050 \\
(0.321)\end{array}$ & & $\begin{array}{l}0.114 \\
(0.218)\end{array}$ & & $\begin{array}{l}-0.019 \\
(0.013)\end{array}$ & . & & . & $\begin{array}{l}-0.026 \\
(0.042)\end{array}$ & & 0.00 & 0.99 & 0.08 \\
\hline Norway & $\begin{array}{l}1.015 \\
(0.165)\end{array}$ & $* * *$ & $\begin{array}{l}-0.305 \\
(0.151)\end{array}$ & * & $\begin{array}{l}0.147 \\
(0.212)\end{array}$ & & $\begin{array}{l}-0.043 \\
(0.163)\end{array}$ & & $\begin{array}{l}0.035 \\
(0.141)\end{array}$ & & . & $\begin{array}{l}0.014 \\
(0.008)\end{array}$ & * & . & $\begin{array}{l}-0.011 \\
(0.035)\end{array}$ & & 0.00 & 1.00 & 0.07 \\
\hline Portugal & $\begin{array}{l}-0.075 \\
(0.351)\end{array}$ & & $\begin{array}{l}0.148 \\
(0.296)\end{array}$ & & $\begin{array}{l}1.192 \\
(0.474)\end{array}$ & ** & $\begin{array}{l}-0.387 \\
(0.550)\end{array}$ & & $\begin{array}{l}-0.180 \\
(0.215)\end{array}$ & & $\begin{array}{l}0.024 \\
(0.016)\end{array}$ & . & & . & $\begin{array}{l}-0.136 \\
(0.198)\end{array}$ & & 0.00 & 0.99 & 0.35 \\
\hline Spain & $\begin{array}{l}0.533 \\
(0.227)\end{array}$ & ** & $\begin{array}{l}0.161 \\
(0.223)\end{array}$ & & $\begin{array}{l}0.458 \\
(0.295)\end{array}$ & & $\begin{array}{l}-0.336 \\
(0.294)\end{array}$ & & $\begin{array}{l}0.018 \\
(0.136)\end{array}$ & & $\begin{array}{l}0.003 \\
(0.008)\end{array}$ & $\begin{array}{l}-0.054 \\
(0.016)\end{array}$ & $* \star *$ & . & $\begin{array}{l}-0.090 \\
(0.037)\end{array}$ & ** & 0.00 & 1.00 & 0.19 \\
\hline Sweden & $\begin{array}{l}0.768 \\
(0.203)\end{array}$ & $* * *$ & $\begin{array}{l}0.065 \\
(0.201)\end{array}$ & & $\begin{array}{l}-0.154 \\
(0.175)\end{array}$ & & $\begin{array}{l}-0.168 \\
(0.176)\end{array}$ & & $\begin{array}{l}0.054 \\
(0.070)\end{array}$ & & $\begin{array}{l}-0.014 \\
(0.008)\end{array}$ & $\begin{array}{l}-0.007 \\
(0.010)\end{array}$ & & $\begin{array}{l}0.033 \\
(0.018)\end{array}$ & $\begin{array}{l}-0.042 \\
(0.038)\end{array}$ & & 0.00 & 0.99 & 0.44 \\
\hline UK & $\begin{array}{l}0.980 \\
(0.181)\end{array}$ & $* * *$ & $\begin{array}{l}-0.147 \\
(0.188)\end{array}$ & & $\begin{array}{l}0.050 \\
(0.252)\end{array}$ & & $\begin{array}{l}0.168 \\
(0.245)\end{array}$ & & $\begin{array}{l}-0.168 \\
(0.166)\end{array}$ & & $\begin{array}{l}0.005 \\
(0.010)\end{array}$ & $\begin{array}{l}0.011 \\
(0.015)\end{array}$ & & $\begin{array}{l}-0.017 \\
(0.018)\end{array}$ & $\begin{array}{l}0.005 \\
(0.061)\end{array}$ & & 0.00 & 0.99 & 0.28 \\
\hline USA & $\begin{array}{l}0.998 \\
(0.129)\end{array}$ & *** & $\begin{array}{l}-0.257 \\
(0.126)\end{array}$ & * & $\begin{array}{l}0.240 \\
(0.106)\end{array}$ & ** & $\begin{array}{l}-0.286 \\
(0.117)\end{array}$ & ** & $\begin{array}{l}-0.155 \\
(0.071)\end{array}$ & ** & . & $\begin{array}{l}0.023 \\
(0.005)\end{array}$ & $* * *$ & $\begin{array}{l}-0.003 \\
(0.006)\end{array}$ & $\begin{array}{l}-0.069 \\
(0.028)\end{array}$ & ** & 0.00 & 0.99 & 0.42 \\
\hline
\end{tabular}

1/ Separate regression for each country in the sample; regression relates log of government spending to its own first two lags, two lags of real GDP, the lagged (October of the preceding year) OECD composite leading indicator, beginning-of-

period gross public debt, a lagged financial crisis dummy, a lagged exchange rate peg dummy, a 'bad fiscal times' dummy, a time trend and a constant (not reported here). Point estimate reported in top row, standard error in parentheses below. 
Table 4. Summary Statistics for Estimated Government Spending Shocks 1/

(Percent)

\begin{tabular}{lc}
\hline No. of observations & 444 \\
Mean & 0.04 \\
Median & 0.00 \\
Standard deviation & 1.02 \\
Minimum & -3.57 \\
Maximum & 5.16 \\
Correlation with simple growth rate & \\
of government spending & 0.64 \\
& \\
Five largest negative and positive shocks: & \\
Portugal, 1993 & \\
Netherlands, 1984 & -3.57 \\
Netherland, 2005 & -3.33 \\
Norway, 1988 & -3.18 \\
Spain, 1988 & -2.97 \\
Portugal, 1991 & -2.67 \\
Portugal, 2005 & 2.60 \\
Denmark, 1993 & 2.68 \\
Ireland, 1986 & 2.85 \\
\hline & 3.83 \\
\hline
\end{tabular}

1/ All statistics refer to final sample described in Table 1. 
Table 5. Overview of Dummy Characteristics

\begin{tabular}{|c|c|}
\hline Dummy & $\begin{array}{l}\text { Countries and Time Periods Fulfilling the } \\
\text { Respective Criterion in the Final Sample }\end{array}$ \\
\hline \multirow[t]{12}{*}{ Peg } & Austria, 1978-2008 \\
\hline & Belgium, 1978-2008 \\
\hline & Canada, 1978-2001 \\
\hline & Denmark, 1978-2008 \\
\hline & Finland, 1989-91, 1998-2008 \\
\hline & France, 1982-2008 \\
\hline & Ireland, 1983-2008 \\
\hline & Italy, 1983-91, 1998-2008 \\
\hline & Netherlands, 1978-2008 \\
\hline & Portugal, 1990-2008 \\
\hline & Spain, 1984-2008 \\
\hline & Sweden, 1978-92 \\
\hline \multirow[t]{11}{*}{ Bad fiscal times } & Belgium, 1978-2003 \\
\hline & Canada, 1983-87, 1992-97 \\
\hline & Denmark, 1982-84 \\
\hline & France, 1994 \\
\hline & Ireland, 1983-89 \\
\hline & Italy, 1980-91, 1998-2008 \\
\hline & Japan, 1997-2008 \\
\hline & Netherlands, 1983, 1996 \\
\hline & Portugal, 1991-92, 1994-95, 2006 \\
\hline & Spain, 1986-87, 1994-96 \\
\hline & Sweden, 1983, 1993-96 \\
\hline \multirow[t]{16}{*}{ Financial crisis } & Australia, 1992 \\
\hline & Austria, 2008 \\
\hline & Belgium, 2008 \\
\hline & Canada, 1983-85 \\
\hline & Denmark, 1987-92, 2008 \\
\hline & Finland, 1991 \\
\hline & France, 1994-95 \\
\hline & Ireland, 2007-08 \\
\hline & Italy, 1990-91, 2008 \\
\hline & Japan, 1992-97 \\
\hline & Netherlands, 2008 \\
\hline & Norway, 1988-93 \\
\hline & Spain, 1984-85, 2008 \\
\hline & Sweden, 1991-94 \\
\hline & United Kingdom, 2007-08 \\
\hline & United States, 1984-91, 2007-08 \\
\hline
\end{tabular}



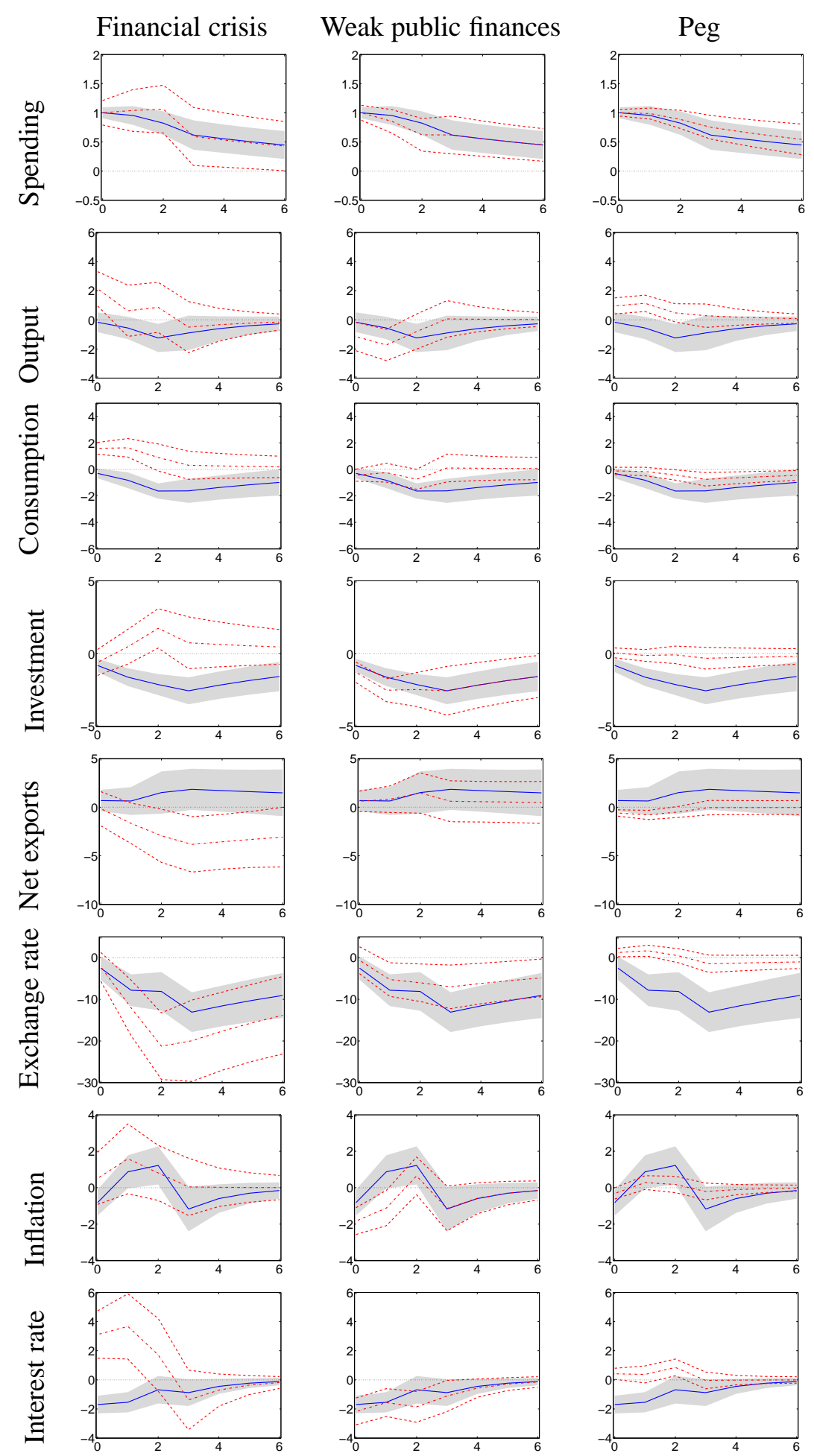

Figure 5: Results for narrow definition of financial crisis. Notes: quantities measured in output units; solid line: point estimate for baseline scenario (shaded area: \pm one standard error); dashed dotted line (dashed lines: \pm one standard error): deviation from baseline under the specific condition indicated on top of column. 


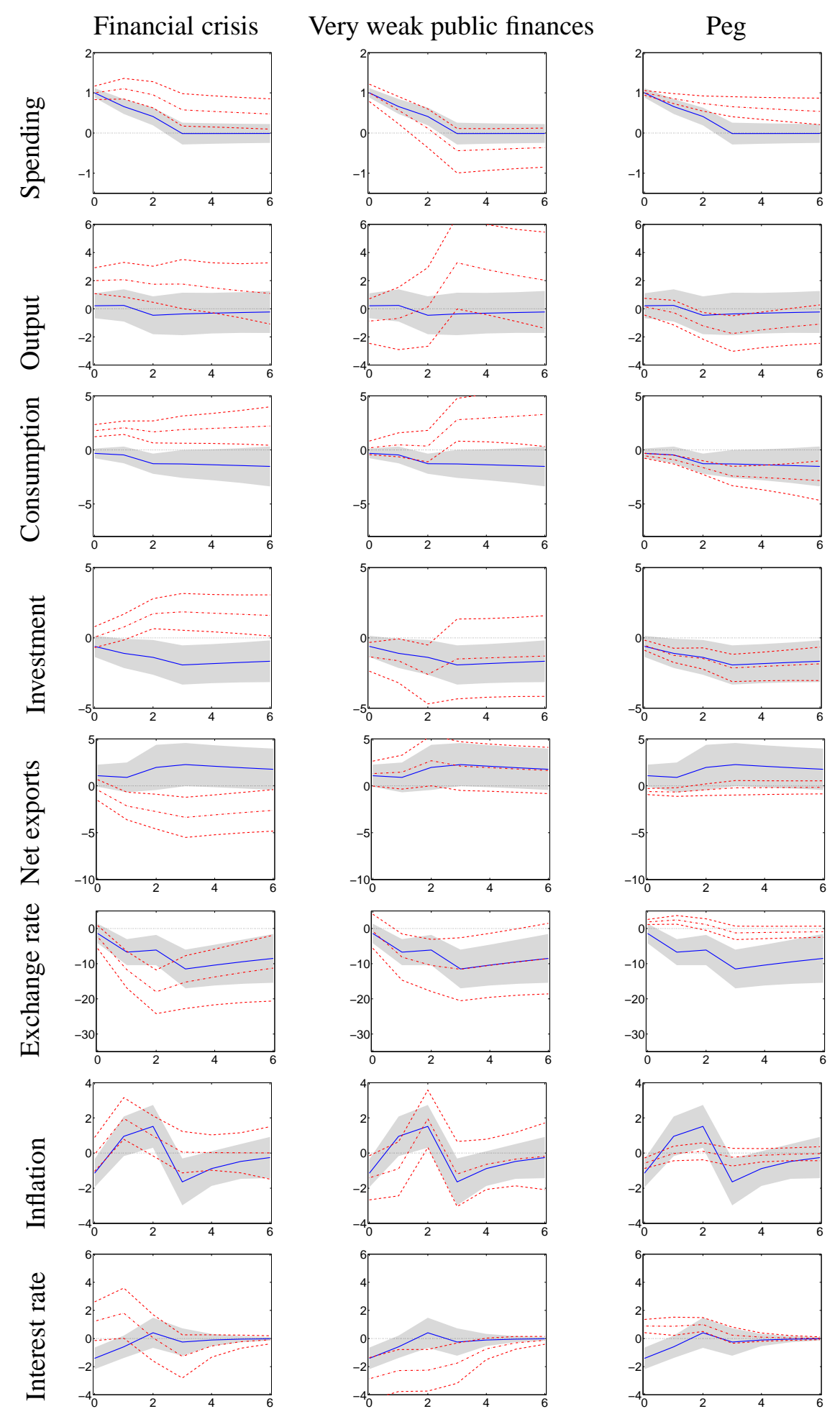

Figure 6: Results for alternative definition of weak public finances (government debt $>120$ percent of GDP and/or lagged net borrowing $>7$ percent of GDP). Notes: see Figure 5. 

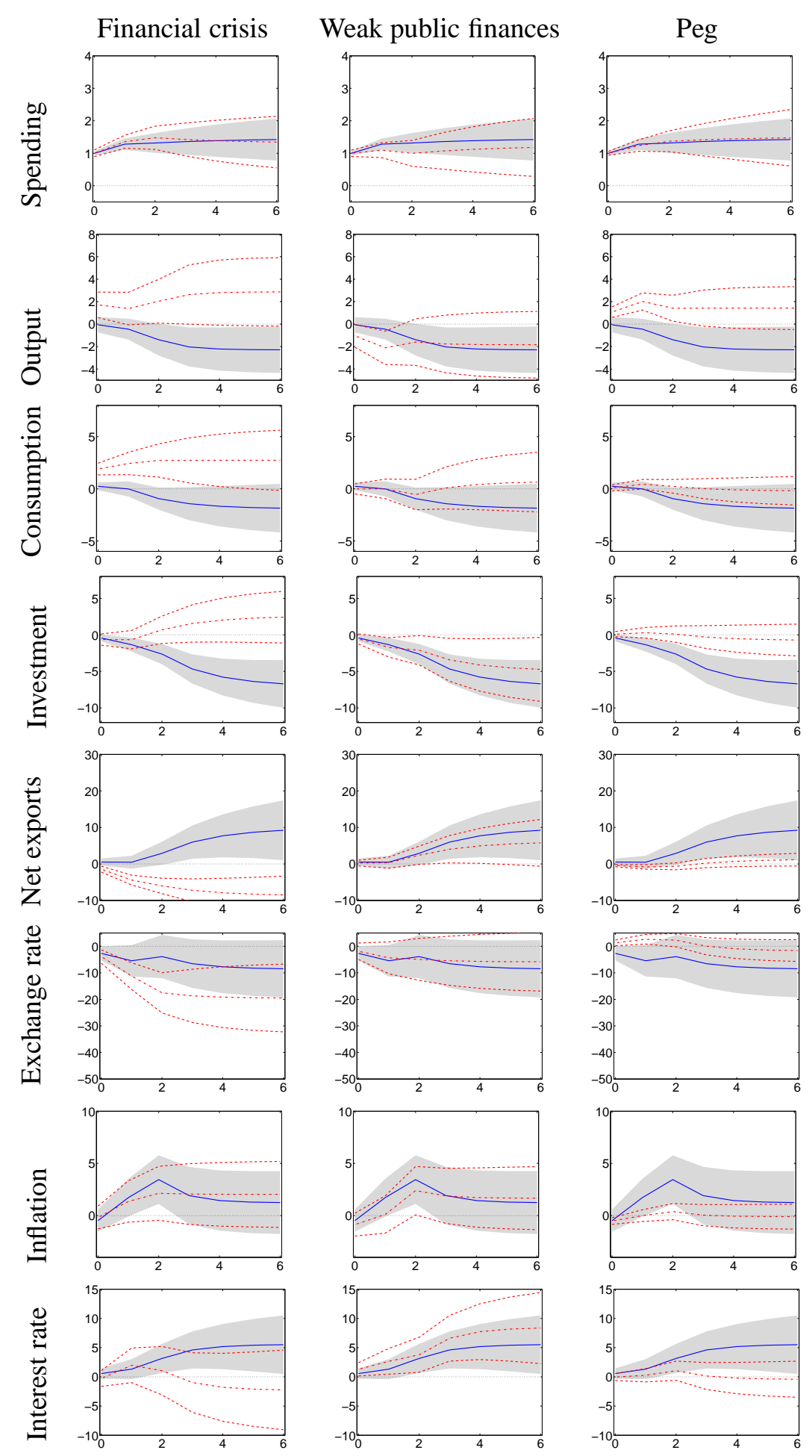

Figure 7: Results for difference specification. Notes: responses display cumulative effect of government spending innovation for model estimated in first differences; quantities measured in output units; solid line: point estimate for baseline scenario (shaded area: \pm one standard error); dashed dotted line (dashed lines: \pm one standard error): deviation from baseline under specific condition indicated on top of column. 


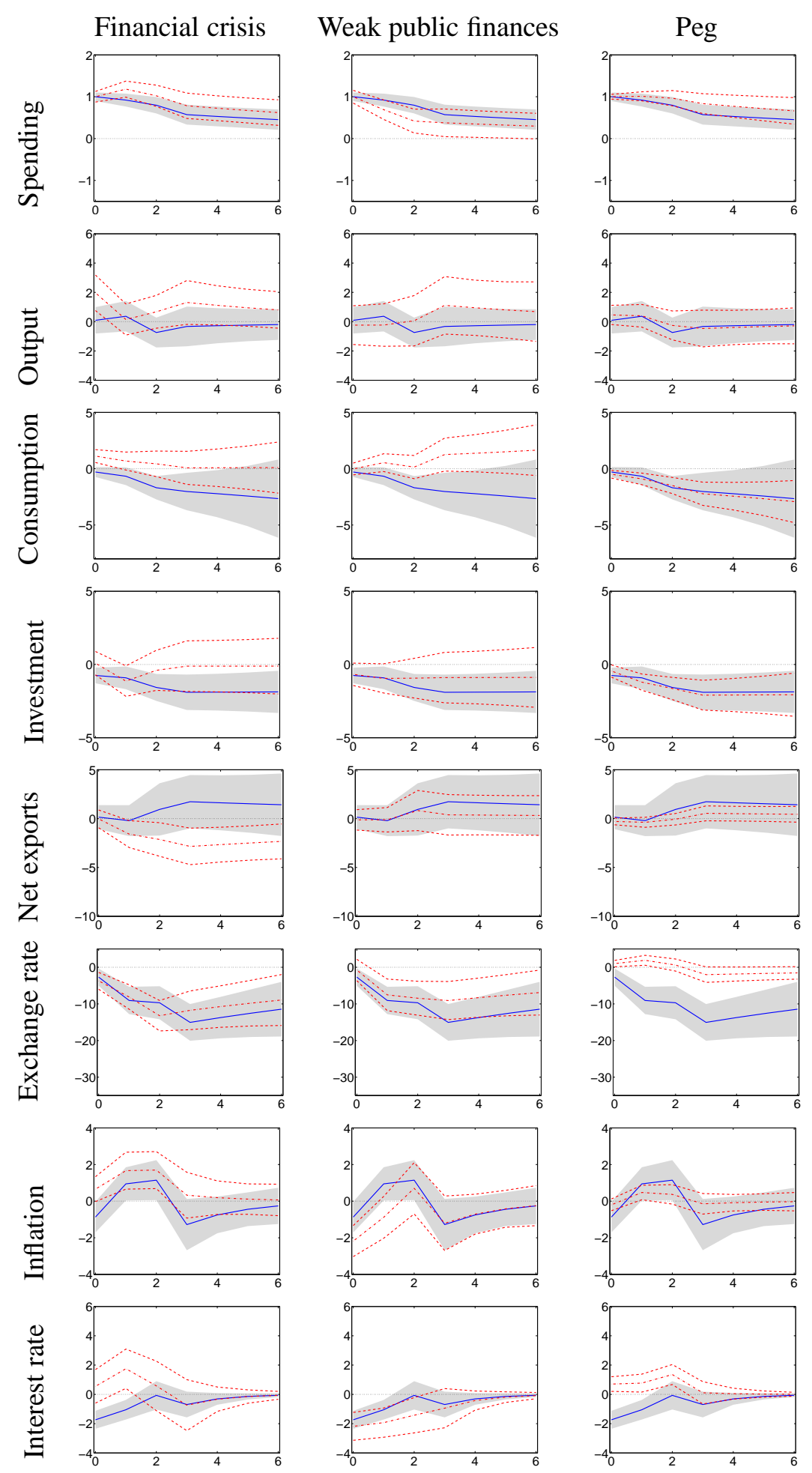

Figure 8: Results for first-step specification which includes contemporaneous value of crisis dummy. Notes: see Figure 5. 

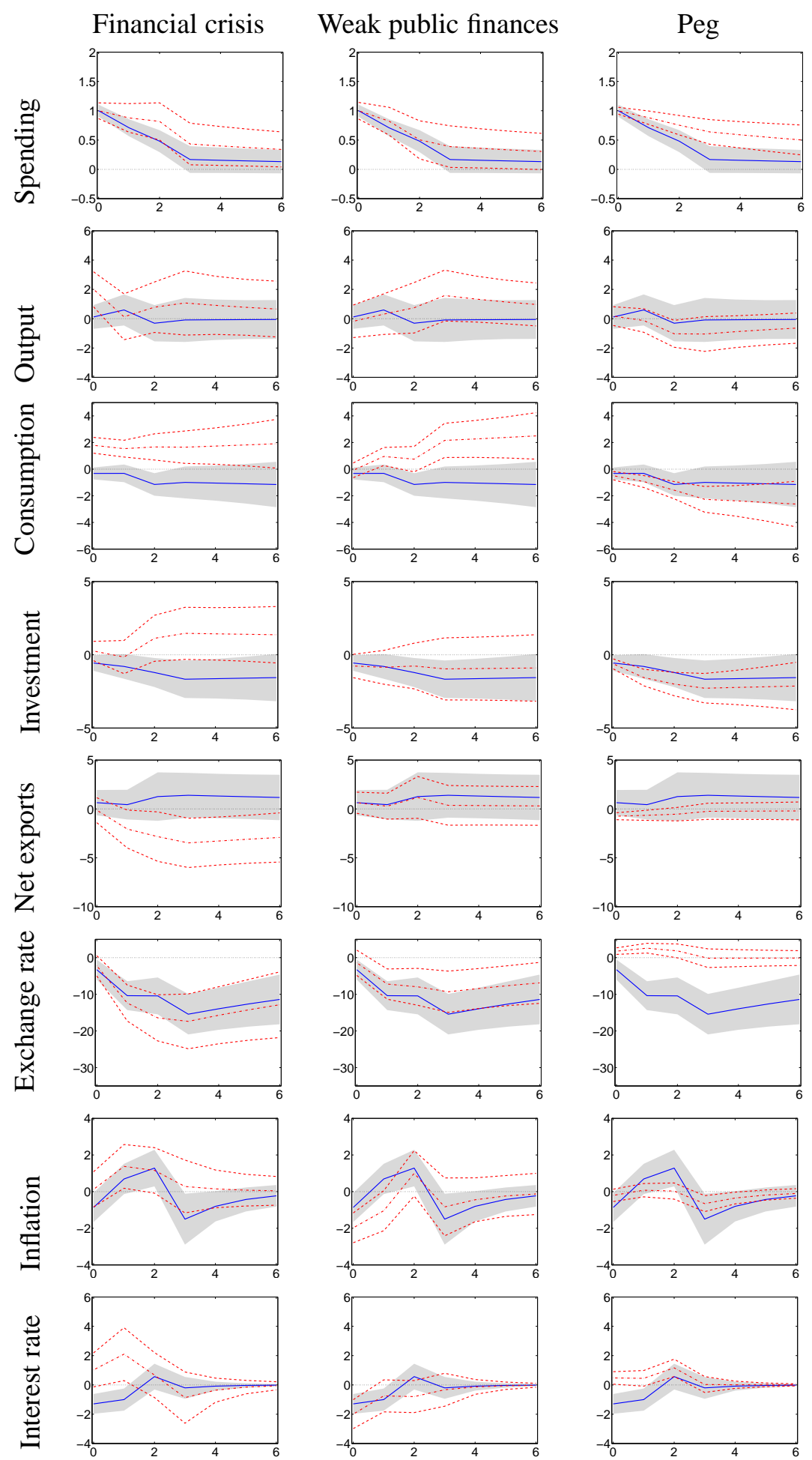

Figure 9: Results without CLI in first step. Notes: see Figure 5. 

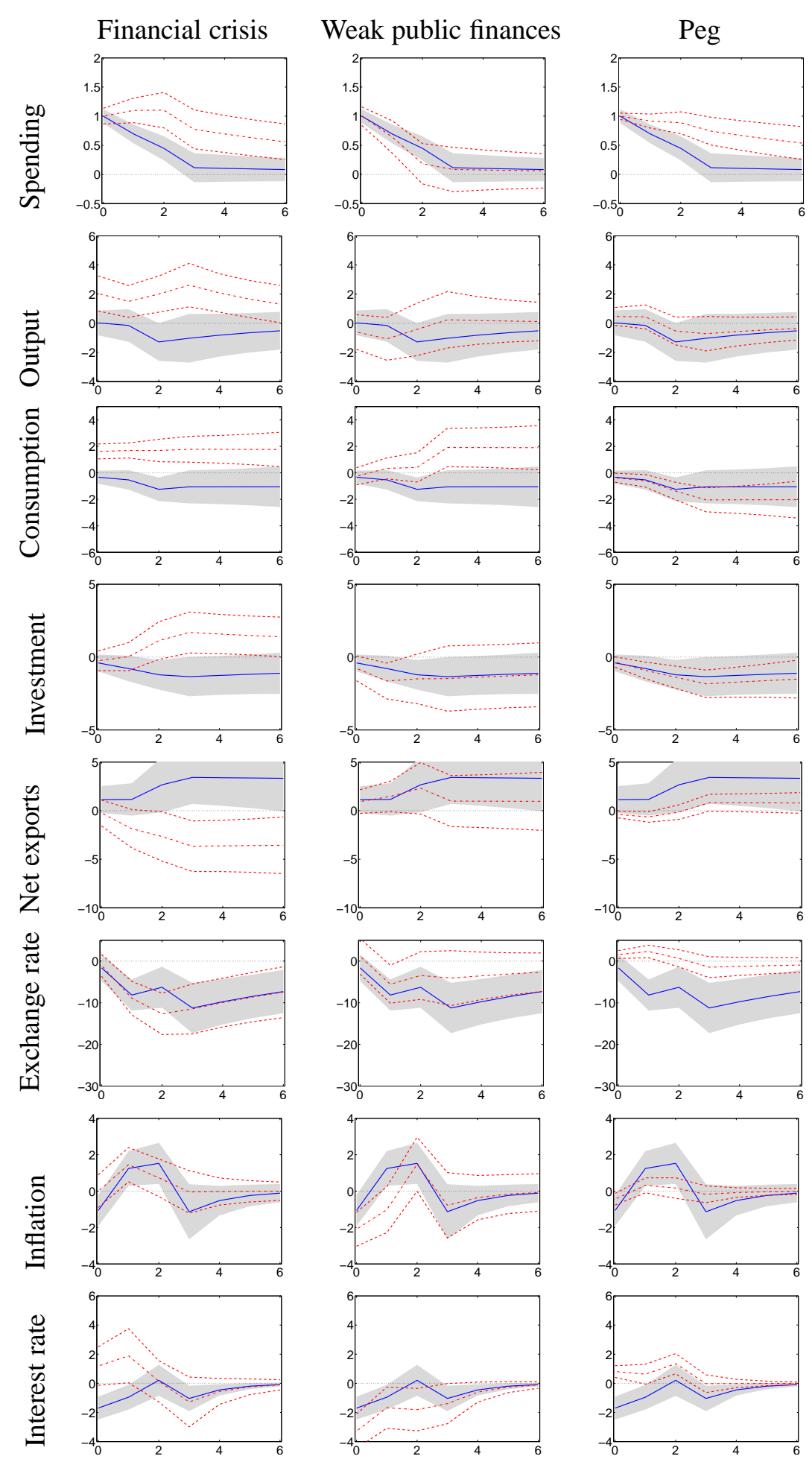

Figure 10: Results for sample without 2007-2008. Notes: quantities measured in output units; solid line: point estimate for baseline scenario (shaded area: \pm one standard error); dashed dotted line (dashed lines: \pm one standard error): deviation from baseline under specific condition indicated on top of column. 

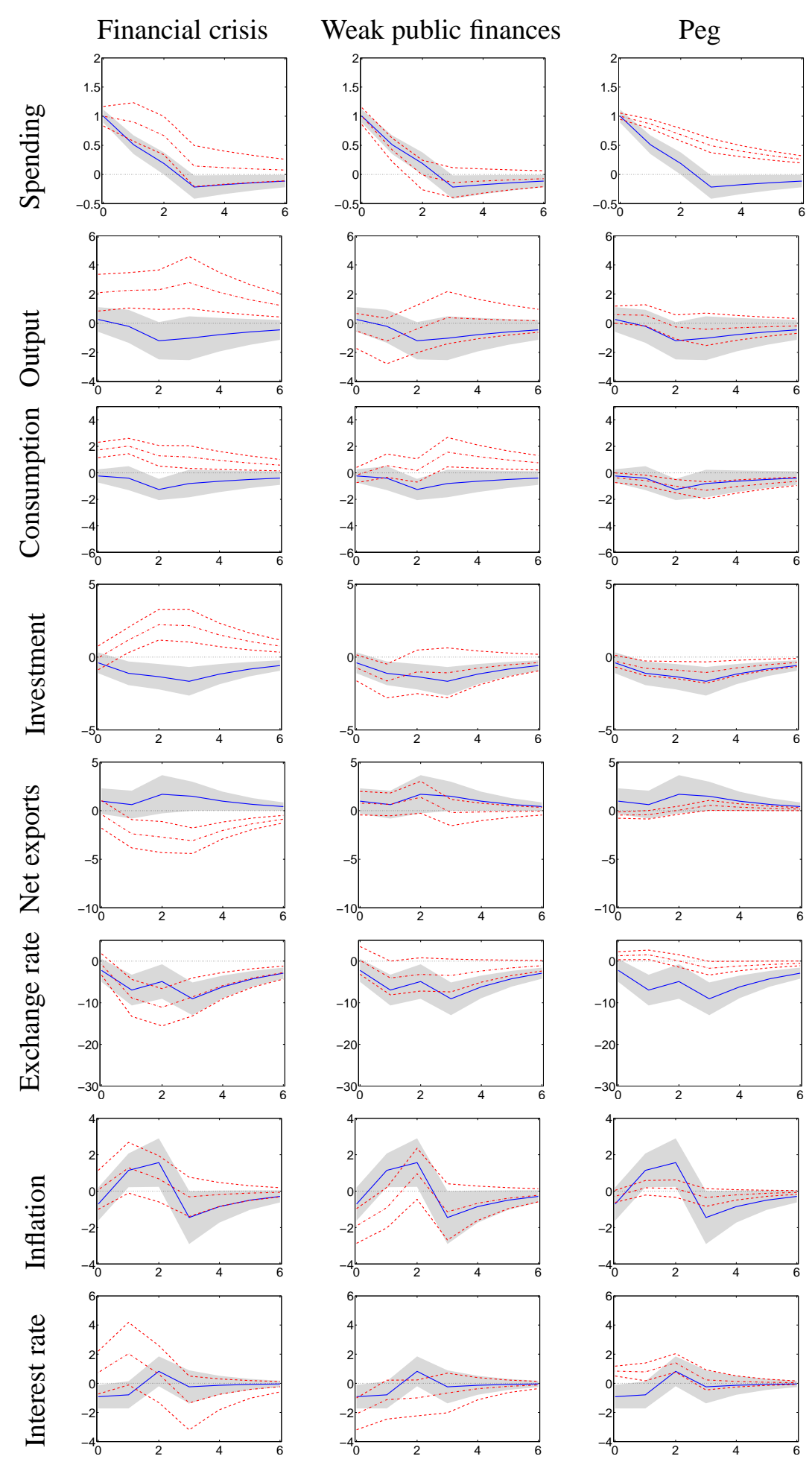

Figure 11: Results for sample without United States. Notes: quantities measured in output units; solid line: point estimate for baseline scenario (shaded area: \pm one standard error); dashed dotted line (dashed lines: \pm one standard error): deviation from baseline under specific condition indicated on top of column. 